\title{
THE MIDDLE ARCHAIC SITE OF PERNIL ALTO, SOUTHERN PERU: THE BEGINNINGS OF HORTICULTURE AND SEDENTARINESS IN MID-HOLOCENE CONDITIONS
}

\author{
EL SITIO DE PERNIL ALTO DEL ARCAICO MEDIO EN EL SUR DEL PERÚ: \\ COMIENZO DE HORTICULTURA Y SEDENTARISMO EN CONDICIONES DEL \\ HOLOCENO MEDIO
}

\author{
Hermann Gorbahn*
}

\begin{abstract}
During the Middle Archaic period, agriculture -that later played an important role- was established in the Central Andes. Pernil Alto was a permanent settlement of this period, dating to 5800-5000 cal BP and located in Southern Peru. The economy was already based on horticulture and was independent from the marine resources of the Pacific Ocean. Nevertheless, some foraging, especially plant collection, was conducted. Currently, the area is one of the driest in the world, but was -based on palaeoclimatic informationmuch more favourable during the Middle Archaic. These conditions certainly influenced the emergence of horticulture in the region.

Key words: Pernil Alto, horticulture, palaeo-landscape reconstruction.
\end{abstract}

La agricultura se ha establecido en los Andes centrales durante el Arcaico Medio. Pernil Alto (5800-5000 calBP) era un asentamiento permanente de este periodo en el sur del Perú. La economía de este asentamiento ya estaba basada en horticultura e independiente de los recursos marinos del Océano Pacífico. No obstante el uso de recursos naturales todavía era importante en la economía, específicamente la colección de plantas silvestres. El área es actualmente una de las más áridas en el mundo, pero era mucho más favorable durante el Arcaico Medio. Esas condiciones influenciaron seguramente la emergencia de la horticultura en esta región.

Palabras claves: Pernil Alto, horticultura, reconstrucción de paleopaisaje.

\section{Introduction}

Sedentariness and agriculture emerged in Peru during the preceramic Middle Archaic Period (80005200/5000 BP). While during the Early Archaic Period (12000-8000 BP) a foraging economy still prevailed, the developments and innovations that occurred during the Middle Archaic Period finally led to the development of complex societies on the Central Peruvian Coast in the Late Archaic Period (5200/5000-2800 BP), starting relatively abruptly at $5200 / 5000 \mathrm{BP}$ and leaving monumental architecture, for example, in Sechín Bajo ${ }^{1}$ in the Casma Valley and $\mathrm{Caral}^{2}$ in the Supé valley with the contemporary site of Aspero $^{3}$ on the littoral of the same valley (all mentioned sites are mapped in Figure 1). These societies exploited the rich marine resources of the region, but the production of cultivated plants was also already important. Thus, the processes that led to the establishment of farming in the Late Archaic Period took place during the Middle Archaic Period, but are far from being completely understood due to rather sparse and scattered evidence.

During the Middle Archaic Period, a foraging way of life prevailed in the highlands of the Central Andes. Sites like Asana ${ }^{4}$ in the extreme south of Peru as well as Panalauca ${ }^{5}$ and the Pachamachay cave $^{6}$ in the Central Peruvian Junín area showed a hunting-based economy for this period. Towards the end of the Middle Archaic Period, a trend towards more sedentariness is assumed for the last two sites, even though critically reviewed ${ }^{7}$. A shift from camelid hunters to pastoralists and the domestication of camelids can be detected in the remains of cave sites such as Telarmachay ${ }^{8}$ and Uchkumachay ${ }^{9}$ in the Junín area in the highlands from about $5500 \mathrm{BP}$ onwards.

On the Pacific littoral, early and probably permanent settlements developed such as La Paloma ${ }^{10}$ on the Central Peruvian and the sites of the Las Vegas culture in Southern Ecuador ${ }^{11}$. From coastal sites like these, the earliest domesticated food plants from

* Kiel University, Commission of Extra-European Cultures German Archaeological, Institute/ Graduate School "Human Development in Landscapes”, Alemania. Correo electrónico: hgorbahn@ gshdl.uni-kiel.de 


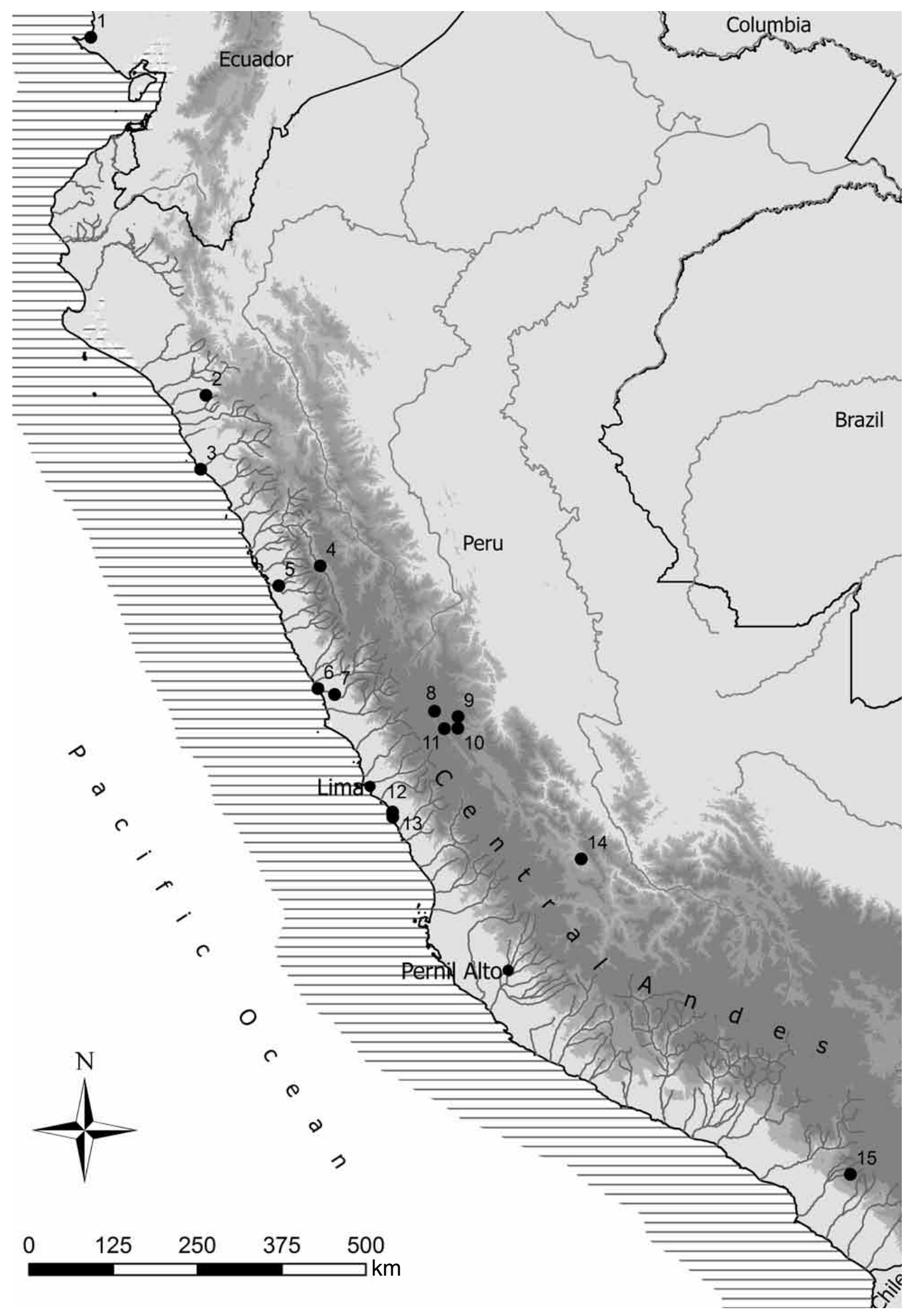

Figure 1. Map showing the location of Pernil Alto in the Central Andes. The sites mentioned in the text are indicated: 1 - Las Vegas, 2 - Zaña valley, 3 - Huaca Prieta, 4 - Guitarrero Cave, 5 - Sechín Bajo, 6 - Aspero, 7 - Caral, 8 - Pachamachay, 9 - Telarmachay, 10 - Uchkumachay, 11 - Panaulauca, 12 - La Paloma, 13 - Chilca, 14 - Ayacucho region, 15 - Asana. 
the Central Andes are known. The oldest directly dated domesticated food plant so far is the lima bean (Phaseolus lunatus) ${ }^{12}$ from the site of Chilca $1^{13}$, close to La Paloma. The previously assumed oldest domesticates from the Guitarrero Cave ${ }^{14}$ in the Callejón de Huayalas in the Peruvian highlands were probably intrusive and dated to about 5000 cal $\mathrm{BP}^{15}$. Recent investigations on the site of Huaca Prieta $^{16}$ on the Northern Peruvian coast, which was considered as a Late Archaic site for decades, revealed much older layers and the cultivation of domesticated food plants even during the Middle Archaic Period ${ }^{17}$. Nevertheless, the exploitation of the rich marine resources of the Humboldt Current formed the basis of the diet at these sites ${ }^{18}$.

In the Zaña Valley in Northern Peru, at a distance of about $80 \mathrm{~km}$ from the coast, a shift from foraging to farming was observed during the Tierra Blanca Phase (7800-5000 BP $)^{19}$ when plant production was intensified and squash, peanuts, plum, manioc, a quinoa-like chenopod, coca and cotton were cultivated in addition to the exploitation of wild resources, but maize and beans were still unknown or at least unused.

Further to the south in the Ayacucho region of the Southern Peruvian highlands, a large botanicalarchaeological project was conducted under the supervision of R. MacNeish in the $1970 \mathrm{~s}^{20}$. During the Piki phase (7750-6350 BP), domesticated plants such as quinoa, calabash and possibly squash were cultivated, but wild resources were still of high importance. In the following Chihua phase (6350$5050 \mathrm{BP}$ ), beans, achiote, coca, lúcuma and possibly potato were cultivated and a more established plant production regimen was of higher importance for the economy.

Thus, the developments that finally led to an established farming economy in conjunction with the exploitation of the marine resources on the Central Peruvian coast transpired during the Middle Archaic Period, but are so far not well-known and not detectable on the Central Peruvian Coast itself. It would seem that early domesticated or cultivated food plants can be interpreted as a "by-product" of sedentary communities of the coast whose economy was still dominated by foraging. The question is when and where the "by-product" of produced plants became more important for the economy and exceeded wild resources. For an understanding of the development, it is less important to find the first domesticated food plants, but rather the sites where those plants played an important role in the alimentation of the inhabitants ${ }^{21}$.

These developments were accompanied by climatic situations different than those which are found today. The questions are raised, if and how the prevailing palaeoclimatic situations influenced the development during the research time span and if more favourable or less favourable conditions impacted the changes.

The complex picture consists of different puzzle pieces that led to early farming which formed the base of complex societies in the Late Archaic Period. One further puzzle piece can be added to this complex development with the results of the excavations of the Middle Archaic site of Pernil Alto in the Río Grande Valley in Southern Peru. It was possible to identify various domesticated plants from this site that were probably produced in a horticulture economy. Of some interest are the ecological circumstances that provided the background for this development in this currently extremely arid area that is just fed with water from some rivers that cross the desert plain.

\section{Location of Pernil Alto and research history}

Pernil Alto is located on the foothills of the Andes at an elevation of $388 \mathrm{~m}$ a.s.l., on the right margin of the Río Grande River Valley in the area of the modern town of Palpa in Southern Peru. Following the Río Grande River, the littoral is at a distance of about $60 \mathrm{~km}$, while the higher zones of the highlands are at a distance of about $50 \mathrm{~km}$. The site is situated on a small spur that towers about 10 $\mathrm{m}$ above the fertile river valley bottom (see Figure 2).

The archaeological site of Pernil Alto was detected within the Proyecto Arqueologíco Palpa (PAP) in 2000 and registered under the number PAP-266. From 2001 onwards, the site has been excavated, aiming at a four-phase settlement of the Initial Period (3090-2840 BP) ${ }^{22}$. During the excavation campaign of 2005, three burials dating to the Middle Archaic Period were detected in layers below the remains of the Initial Period occupation. This older occupation was separated from the occupation of the Initial Period by a hiatus of about 2000 years.

The following excavation campaigns in 2007, 2008 and 2009 were aimed at the excavation of the remains of the Middle Archaic Period, since it was poorly examined for the area of Southern Peru so far and no large-scale excavations had been 


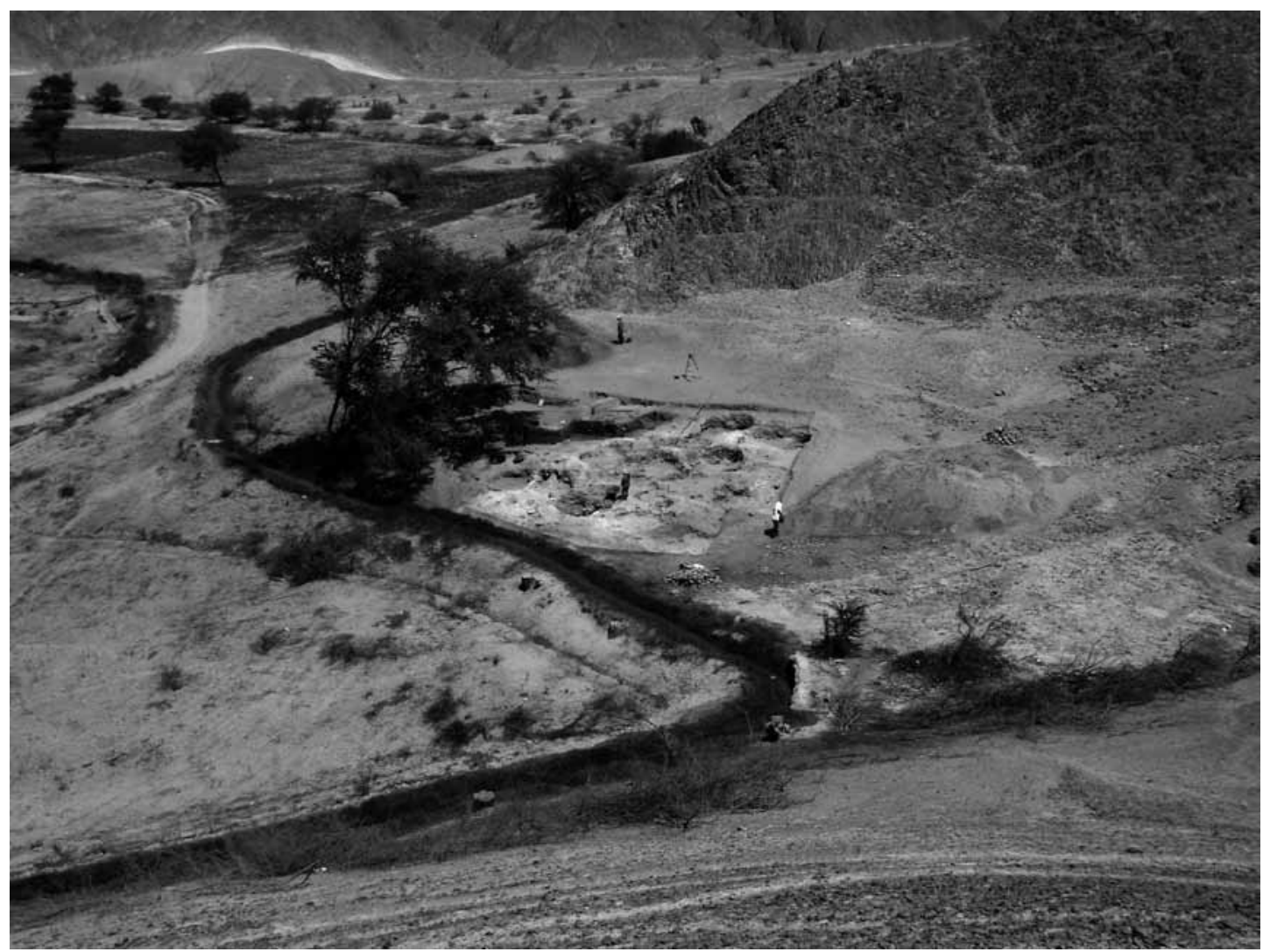

Figure 2. The site of Pernil Alto in the acutal setting. The northern excavation area is visible. Note the large pits. View to the west.

previously carried out. The mentioned excavations did not remove the wall remains of the occupation of the Initial Period which are located at the centre of the site (Figure 3). Thus, two areas -one in the northeast and one in the southwest that are separated by the remains of the younger occupation- were excavated and provided information on the Middle Archaic settlement. Nevertheless, some remains of the same occupation can be assumed to be located below the unexcavated wall remains.

\section{Preceramic sites in the Río Grande Basin}

Some small scale excavations and surface detections of preceramic sites in the region have been reported (these sites are mapped in Figure 8). W. D. Strong documented a site consisting of some shell mounds in the Bay of San Nicolás ${ }^{23}$. The site of Santa Ana, located on the estuary of the Río Grande River, was detected by F. Engel ${ }^{24}$. Both sites seem to date to the Early Archaic Period. Close to the Nasca site of Cahuachi, the site of La Esmeralda was excavated by J. Isla Cuadrado ${ }^{25}$. Recently, the rock shelter of Las Brujas in the lower Río Grande Valley was excavated by B. Vogt, It shows some Middle Archaic layers covered by younger layers, but the research is still ongoing ${ }^{26}$. The Late Archaic site of Upanca, west of the modern town of Nazca, was excavated by K. Vaughn and M. Linares Grados ${ }^{27}$. Thus, Pernil Alto represents the only Middle Archaic site known so far with plant production in the area.

\section{Excavation}

At Pernil Alto $400 \mathrm{~m}^{2}$ have been excavated, aiming at the Middle Archaic occupation (Figure 2 and 3). Two separated excavation areas were located at the northern and the southern parts of the site. As they were situated on the outer zones of the spur, they were strongly inclined on the edges towards the fertile river valley bottom. The erosion at these parts of the excavation was thus stronger than in the centre and resulted in the destruction of parts 


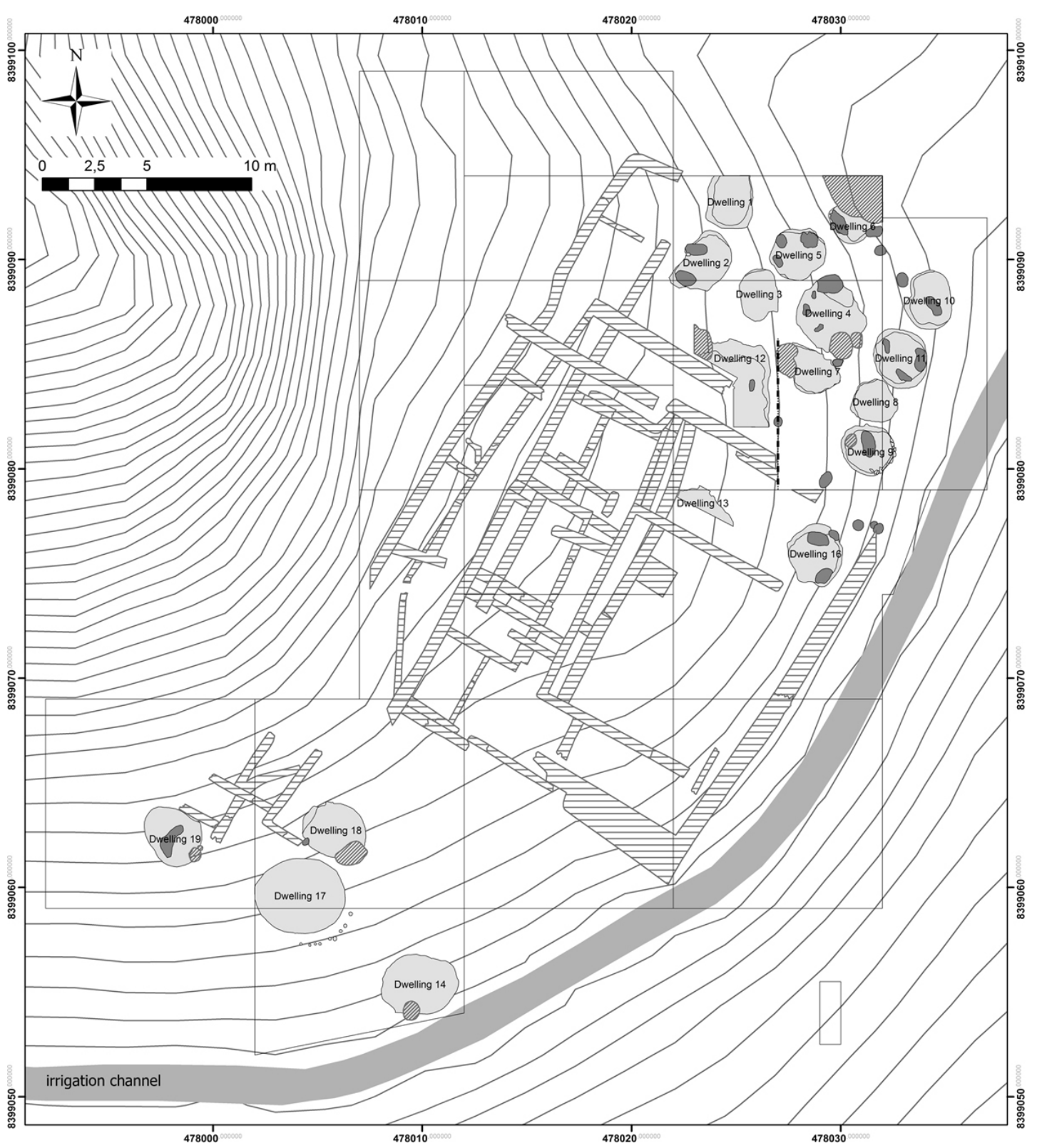

Figure 3. Plan of Pernil Alto. The dwellings of the Middle Archaic occupation are marked in light grey, the burials in darker grey. The wall remains are given in wide lined areas, disturbances of Archaic remains in narrow lined areas. The irrigation channel is modern. The squares reflect the excavation units. The dotted line in the northeast indicates the location of the shown perfile (Figure 4).

of the occupation layers there. This is particularly the case for the southern excavation area, where the remains of the Middle Archaic occupation were less well preserved and the layers were very thin. But a clear stratigraphic sequence of the Middle Archaic occupation was recovered in the western part of the northern area, where erosion had not destroyed the remains of the preceramic occupation (Figure 4).
The excavation was carried out following the cultural layers. Due to the aridity of the area, preservation was very good and macro-plant remains as well as textile remains made of plant fibres were recovered and collected. During the excavations numerous samples suitable for radiocarbon dating were collected. From these samples, 70 were analysed by laboratories in Heidelberg and Mannheim. The plant, 


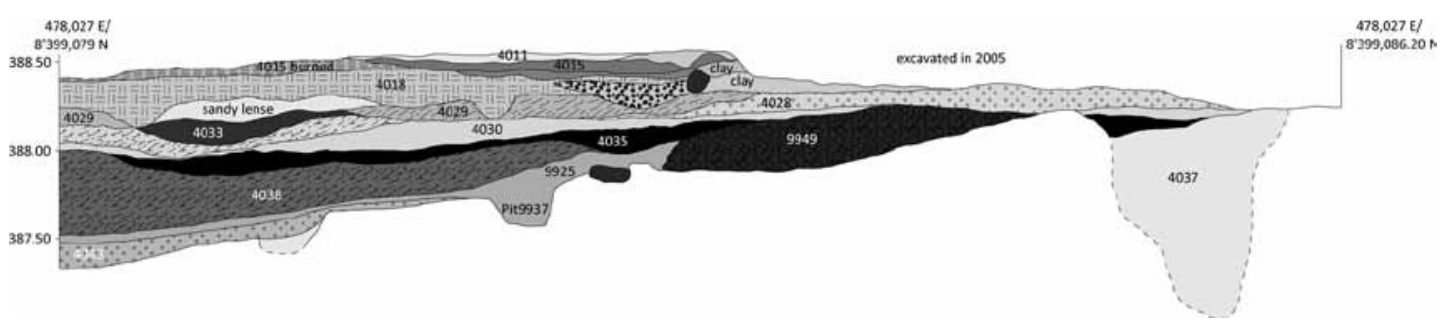

Figure 4. West perfile of the center of Pernil Alto. The Middle Archaic layers are 4038, 9925 and 4043. Superposed are layers of the Initial Period occupation. The location of the perfile is indicated in the site plan (Figure. 3).

animal and shell remains were given to specialists to make adequate and precise determinations ${ }^{1}$. The human remains from the excavated burials were analysed regarding information on ages and sexes of the individuals. Further investigations on the human remains are ongoing ${ }^{2}$.

Samples for $\mathrm{Sr}$-isotope analyses from the teeth of the individuals were taken and analysed ${ }^{3}$.

\section{The Middle Archaic occupation}

\section{Dwellings}

The excavation brought the remains of a settlement of the Middle Archaic Period to light. It consisted of 18 circular to oval pit dwellings (see Figure 3). Those were carved into the natural surface, had diameters ranging from $250-300 \mathrm{~cm}$ and were between 40 and $80 \mathrm{~cm}$ deep (Figure 5). Not all of them were excavated completely, as they were either partly covered by later walls (dwellings 12 and 13), or partly destroyed by later intrusions (dwellings 6, 4, and 7). Except for dwellings 1 and 3 , they contained domestic remains in the form of filling or occupation layers, small fireplaces and pits. Furthermore, most of the detected burials were found within the dwelling remains. According to stratigraphic observations, the burials were deposed

1 Most sincere thanks are extended to Gabriela Bertone of the UNMSM in Lima who determined the macro-plant remains, to Carmen Rosa Cardoza and Enrique Angulo of the Museo de Arqueología de San Marcos in Lima who determined the faunal remains and to Manuel Goritti of the same institution who determined the shell remains.

2 Most sincere thanks go to Elsa Tomasto of the PUCP in Lima who analysed the ages and sexes so far and is concerned now with further research.

3 Most sincere thanks are also extended to Stefan Hölzl, Christian Dekant and Susanne Hummel of the Bayrische Staatssammlung für Paläontologie und Geologie of the LMU in Munich. in the dwellings after the abandonment of the same. Thus, the dwellings were first used as dwellings and later as burial areas. The remains of post holes were not preserved in most of the dwellings. They were probably not very deep or the posts of the roof constructions were not dug in, but leant against the pit-walls. Such dwellings can be reconstructed according to a reconstruction of a dwelling from Chilca 1 on the Central Peruvian coast ${ }^{28}$ and were thus of conical shape and tent-like.

\section{Settlement Structure (compare Figure 3)}

The dwellings were arranged around free areas. Dwellings 1, 2, 3 and 5 were arranged in a circular manner in the north area of the excavation site. No domestic features were detected in the free space between them. In the northeast section of the settlement, dwellings 4, 6, 10 and 11 were also arranged in a more or less circular manner. Pits and fireplaces were located in the area between them. Dwellings 7, 8, 9, 12, 13 and 16 were arranged around a wider, but circular space as well. On this free space the most intensive remains of domestic activities in the form of thick occupation layers, fireplaces and pits were found. The situation of the matrices $14,17,18$ and 19 that were located in the southern area of the excavation is not that clear. Nevertheless, an arrangement of matrices 17-19 could be estimated. Due to the described locations of the dwelling remains and the reconstruction of the dwelling forms it can be assumed that the dwellings were mainly used for sleeping, whereas all-day activities took place in court-like areas between them and in a central larger area. But according to the stratigraphy and the applied radiocarbon dating, the dwellings were not of simultaneous use. It appears that after the abandonment of a dwelling a new one was erected at the same court, respectively the centre, and 


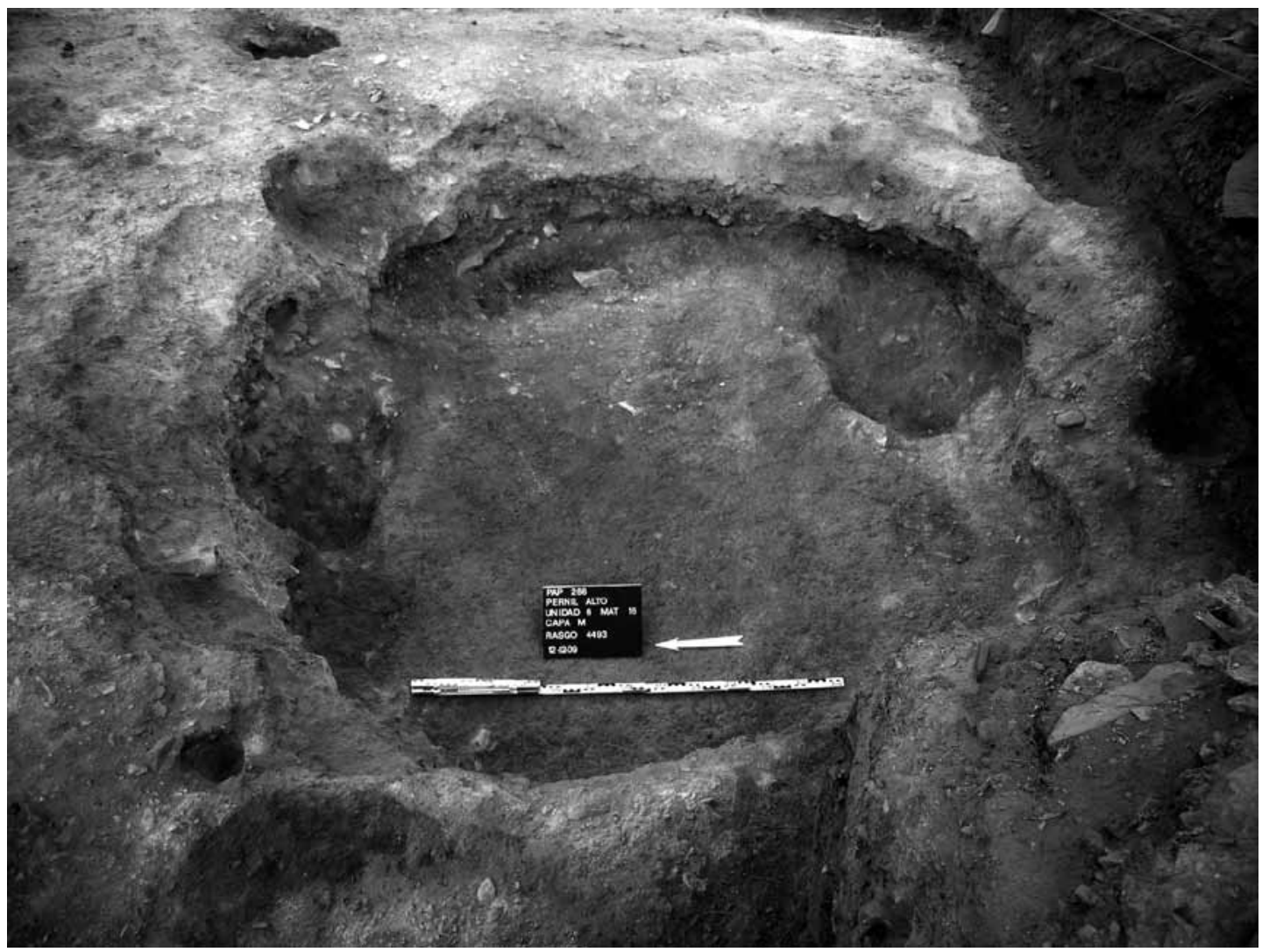

Figure 5. Circular pit of a dwelling (Dwelling 16). View to the east.

the abandoned dwelling was then used for the deposition of burials. It can merely be speculated whether kinship played a role in this system of "revolving courtyards" but it cannot be verified with the available data.

\section{Burials}

Within the settlement, 34 burials including 36 individuals were detected (Figure 3). 29 of them were primary single burials, two were primary double burials and three were disturbed burials. 22 of the burials were located within abandoned dwellings and the remaining eleven irregularly distributed on the site. The individuals were deposited in simple pits generally in flexed positions (Figure 6), wrapped in mats made of plant fibres and the graves were covered in some cases with big stones, probably for marking purposes. In contrast, the body positions, forms of the pits and the markers vary to a great extent, indicating nonstrict burial rites. The grave goods were-except for those from two burials- rather sparse and mostly limited to the remains of the wrapping mats and oval or discoidal shell beads.

\section{Artefact composition}

Among the artefacts found in Pernil Alto, lithic, bone, wood, shell and plant fibre materials were excavated (Figure 7). The lithic industry was simple and consisted of simple flake tools made in hard-punch techniques from andesite, rock tools, and very few obsidian remains. The raw material was found in the river valley bottom in high amounts and is thus located "in front of the door". Just two projectile points and some few debitage were of obsidian (one is shown in Figure 7p). The source of this material was probably located in Quispisisa in the region of Ayacucho ${ }^{29}$, at a linear distance of about $100 \mathrm{~km}$ from Pernil Alto, but with an altitudinal difference of 3400 meters. Nevertheless, measured by its weight more than $99 \%$ of the raw material of the lithics was of local origin. 


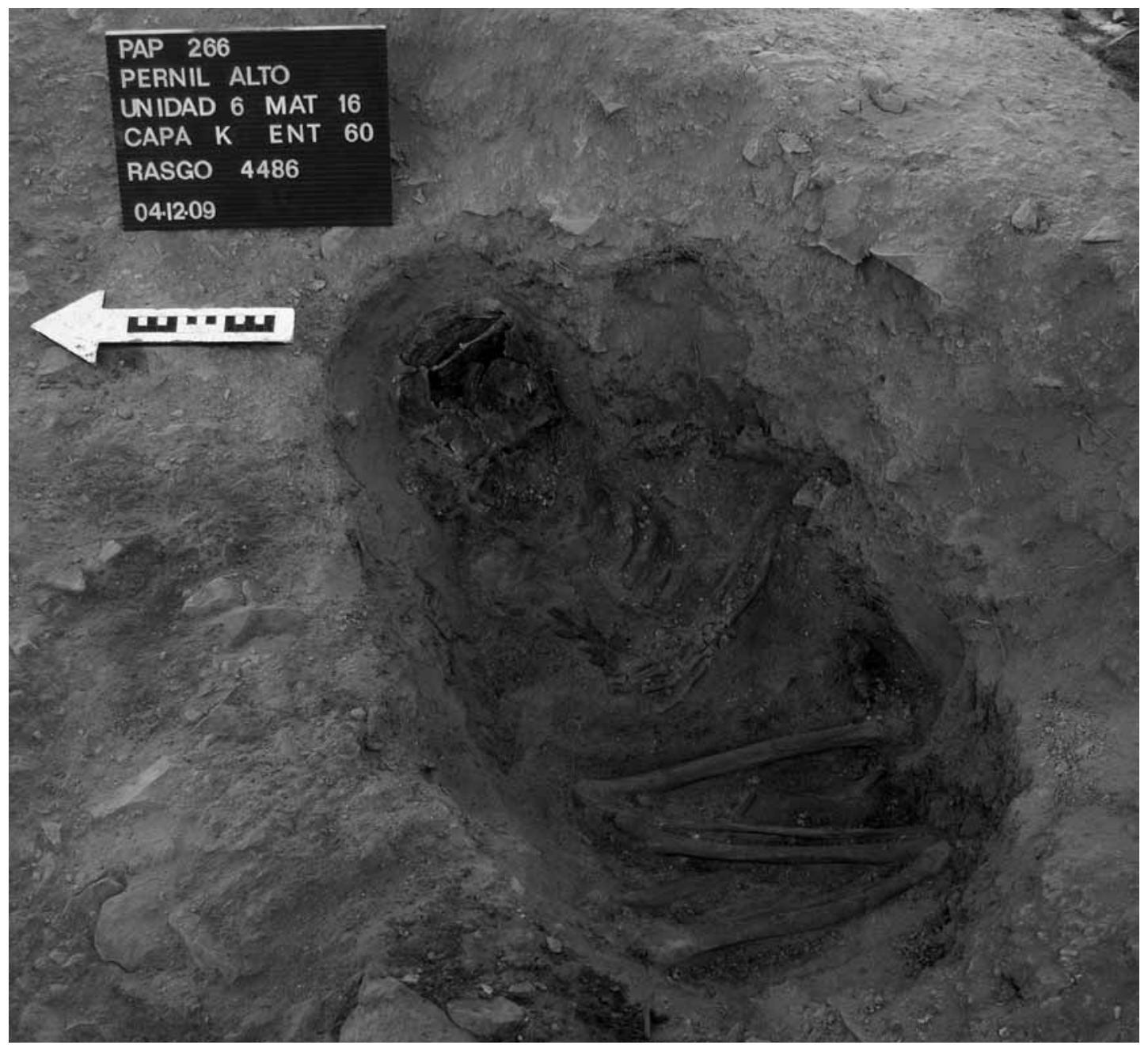

Figure 6. Burial of an adult individual within a dwelling (Burial 60, dwelling 16). View to the east.

The lithic tool assemblage consisted of abundant simple cutting tools (Figure 7a-b), some borers, few scrapers and notched pieces (Figure 7f) . Four heavy cortex flakes showed wear from usage and were possibly utilized for digging or carving into the hard natural surface. Furthermore, core-stones, hammerstones, production debitage and retouchers were detected. They show that lithic production was carried out on the site.

The unpunched rock tools consisted of a high amount of handstones (Figure 7e), small ground stones with a weight of less than $10 \mathrm{~kg}$, big ground stones with weights between 10 and $30 \mathrm{~kg}$ (Figure $7 \mathrm{c}-\mathrm{d})(\mathrm{n}=10)$ and one mortar (Figure 7i) with a weight of $25 \mathrm{~kg}$.

The remaining lithic artefacts were mainly fragments and in some cases may have been cooking stones.
The lithic assemblage shows some characteristics. Exotic materials did not play an important role. Furthermore, the lithic assemblage was mainly designed for the processing of plants as shown by the amounts of handstones, ground stones and the mortar. Cutting tools and the notched pieces could possibly be added to this group, suggesting they were used for cutting plants and carving wood. Taking the lithic assemblage into account, hunting was not of high importance or was conducted by using different hunting techniques. Nevertheless, the faunal remains and artefacts made of bone show that hunting was practiced to some extent.

The 19 bone artefacts could be separated into textile tools (Figure 7j), spatulas, bone pendants, one spear-thrower head, and one figurine. 


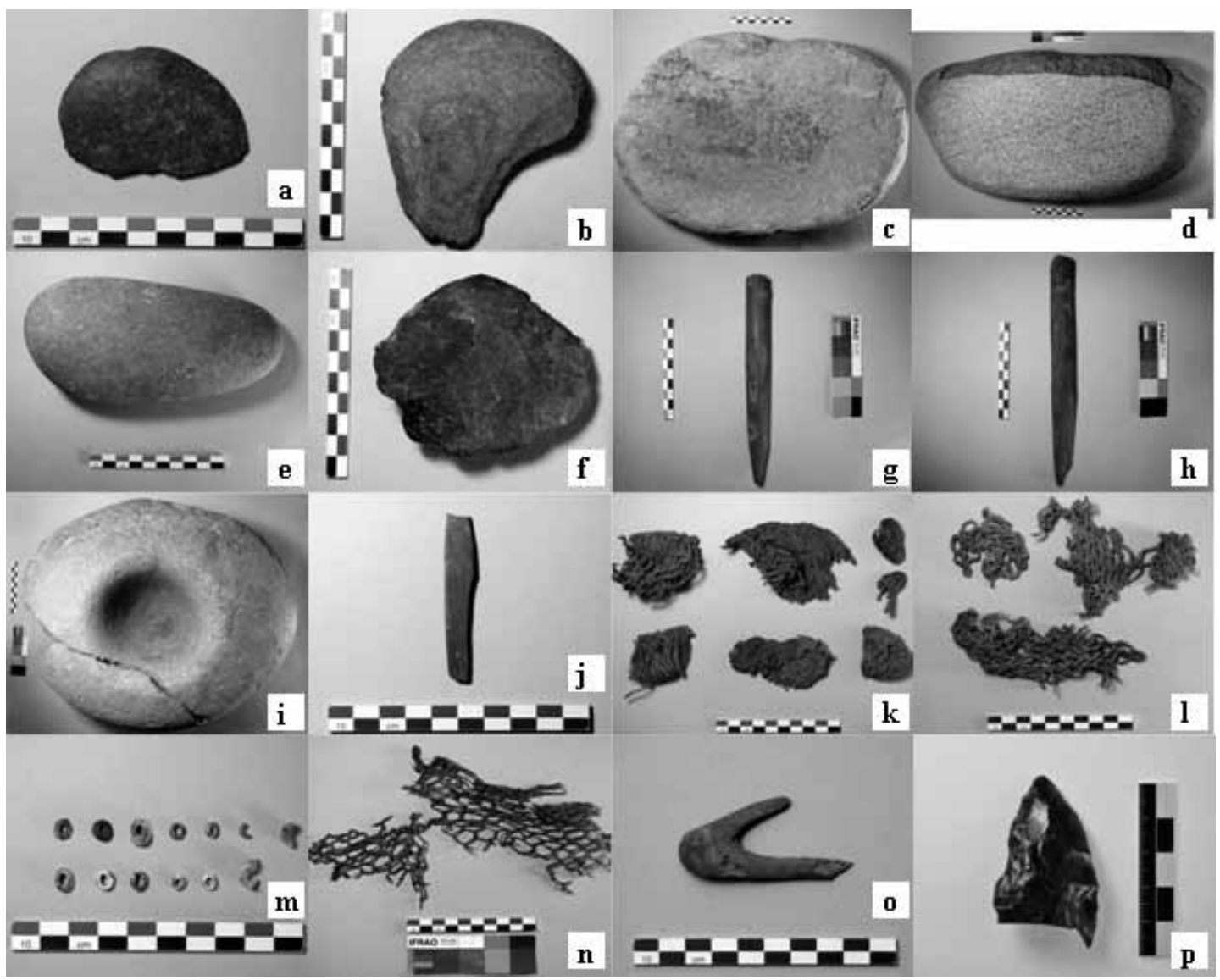

Figure 7. Examples of findings: a-b: cutting tools, c-d: ground stones, e: handstone, f: notched piece, g-h: digging sticks, i: mortar, $\mathrm{j}$ : textile tool fragment, k: mat remains, l: meshed textile remains, m: oval shell beads, n: net remains, o: spear thrower head, p: projectile point. (Note the different scales. The reference scale in a-o is $10 \mathrm{~cm}$, in p $5 \mathrm{~cm}$.).

Among the numerous wooden artefacts, stick remains of indeterminate function were found, including some awls, a few tools for fire making and digging sticks (Figure 7g-h). Even though the information from the wooden artefacts is rather sparse, the digging sticks are tools typically used in horticulture.

The recovered textiles were in different stages of preservation. Thus, exact counts are difficult. They were all made of plant fibres. The applied technique involved simple interlinking, forming meshed textiles (Figure 7l) of unknown function. Furthermore, simple mats were found (Figure 7k), whereby numerous strings, cord remains and some grass fibres neatly wound up to bundles were recovered, indicating textile production on the site. Six remains of knotted nets were found within the material (Figure 7n), but their separation is difficult as some of them were recovered in a very fragmentary condition and together within the same features. Thus, they could represent fragments of less than six nets.

The remains of 323 artefacts made of shells of sea mussels and snails were among the material remains. The majority of these were small oval beads made of Fissurella sp (Figure $7 \mathrm{~m}$ ). Very few complete shells were recovered and it appears that shells were collected in more or less frequent forays to the coast which is a walk of about 2 days time. Thus, mussels and snails were not or nearly never consumed within the site. Maybe -as their use as jewellery indicates- they were exchanged with other groups from the coast.

\section{Dating}

Based on stratigraphic observations, the analysis of all excavated features within a Harris-matrix, and 
the integration of 69 radiocarbon dates, it was possible to subdivide the archaic occupation in Pernil Alto into six phases ${ }^{30}$. First, a Harris-matrix was established that related each feature to its stratigraphic position. Then, based on the assumption that every layer represented a phase, the radiocarbon dates were arranged into a model according to Bayesian statistics using the software OxCal 4.131. Using the "Phase" command in OxCal, the radiocarbon dates were arranged into successive phases resembling the Harris-matrix when they originated from the same layer or -in the case of phases 0 and 5- were dated stratigraphically before or after the layer sequence. Radiocarbon dates that originated from closed contexts were combined to a single age for the respective feature ${ }^{32}$. Furthermore, all dates that were derived from larger layers, such as dwelling remains and burial courts, were arranged according to internal sequences ${ }^{33}$. The calibration of the dates was performed within the model run in OxCal using the calibration curve IntCal09 ${ }^{34}$ with a southern hemisphere correction of $-41 \pm 14$ years $^{35}$. The program returns modelled ages $(\operatorname{modBP})$ for all radiocarbon samples as well as the span and age of each phase (see Table 1).

Some radiocarbon dates did not match parts or all of these settings as they were extracted from locations of the excavation that were either not covered by continuous layers, or where the layers were partly or completely eroded. This was, for instance, the case in the southern area of the Archaic occupation that was "separated" from the northern area by dense wall remains of the occupation of the Initial Period. Thus, several model iterations were accomplished slightly modifying the settings described above and thus integrating stepwise the radiocarbon dates from the stratigraphically isolated locations until those could be added to established phases in the model. The results provided six overlapping phases in which the radiocarbon dates clustered. In this manner, even the features that were not directly radiocarbon dated could be integrated into the phased chronology based on the stratigraphic information extracted from their positions in the Harris-matrix.

The time spans were specified as phases 0 to 5 . Within the $2 \sigma$-range they were dated as (all in $\sigma 2$ ):

- Phase 0: 5905-5291 modBP

- Phase 1: 5334-5265 modBP

- Phase 2: 5303-5146 modBP

- Phase 3: 5270-5047 modBP

\section{- Phase 4: 5249-4996 modBP}

- Phase 5: 5208-4818 modBP

Within these phases, the first phase (0) is just represented by very restricted and non-continuous layers and its dating is relatively widespread. Thus, it could represent, in fact, different phases that were better preserved under the unexcavated parts of the Archaic occupation of the site. Those can be assumed below the dense wall remains of the occupation of the Initial Period in the centre of the site that are not allowed to be removed and where Archaic layers were not reached. Within the phasing established here, phase 0 can be reconsidered as an antecedent phase that does not truly represent a settlement phase ${ }^{36}$.

Phase 5 is a post-occupational phase that is not represented by a layer. Dates from this phase were obtained from a few dwelling remains but mainly from the stratigraphically latest burials. The settlement may have shifted to another location during this phase and the burials were deposited in the older, previously settled location that is represented by Pernil Alto. Another explanation could be that one or some layers of this phase were destroyed by later site-shaping activities during the occupation of the Initial Period.

Phase 2 is an inserted settlement phase. It is not represented by a layer but by numerous features. Integrating the radiocarbon dates into phases 1 or 3 was statistically rejected within the modelling. Therefore, phase 2 was inserted between phases 1 and 3 which produced an accepted radiocarbon model. Thus, phase 2 probably represents a settlement phase that was of relatively short duration or whose layers were removed by later occupants.

The model has an overall agreement of $75.6 \%$. Of the 69 radiocarbon dates, 11 had to be treated as statistical outliers, whose material represented mostly older material that was deposited in younger features (old wood effect).

With the establishment of the six phases of the Archaic occupation of Pernil Alto, the reconstruction of the settlement development is possible even though it must be outlined that these phases -one of which is a "pre-use phase" and another an "after-use phase"- clearly do not necessarily represent exact and strictly separated moments of the settlement, but are to be understood in the sense of time-spans that are chronologically not further divisible under the given circumstances and information. 
Table 1. The radiocarbon dates of Pernil Alto. The model applied in OxCal 4.1 is resembled, indicating the Phases and Sequences $(\mathrm{dwellrem}=\mathrm{dwelling}$ remain; dist burial $=$ disturbed burial; stonecon $=$ stone concentration $)$.

\begin{tabular}{|c|c|c|c|c|c|c|}
\hline Lab-Number / Assignment & 14C Age & calBP $2 \sigma$ & $\operatorname{modBP} 2 \sigma$ & feature type & material & comment \\
\hline \multicolumn{7}{|l|}{ Phase Pernil_o } \\
\hline \multicolumn{7}{|l|}{ Sequence Dwelling 19} \\
\hline Hd-26782 & $5008 \pm 43$ & $5851-5603$ & $5667-5571$ & dwellrem & carred leafs & \\
\hline Hd-26776 & $4930 \pm 44$ & $5717-5558$ & $5650-5554$ & dwellrem & charcoal & \\
\hline Hd-26775 & $4776 \pm 42$ & $5579-5320$ & $5589-5453$ & dwellrem & wood & \\
\hline MAMS-13584 & $4787 \pm 25$ & $5569-5448$ & $5569-5448$ & pit & charcoal & \\
\hline MAMS-13589-2 & $4756 \pm 25$ & $5569-5326$ & $5569-5327$ & dist burial & charcoal & \\
\hline MAMS-13568 & $4653 \pm 23$ & $5434-5281$ & $5432-5305$ & layer & charcoal & \\
\hline Hd-30064 & $4457 \pm 22$ & $5234-4937$ & $5234-4936$ & dwellrem & charcoal & outlier \\
\hline MAMS-13571 & $4752 \pm 25$ & $5567-5324$ & $5567-5324$ & pit & charcoal & outlier \\
\hline MAMS-13566 & $4675 \pm 22$ & $5440-5295$ & $5436-5309$ & layer & charcoal & \\
\hline MAMS-13567 & $4639 \pm 23$ & $5434-5266$ & $5434-5301$ & pit & charcoal & \\
\hline MAMS-13590 & $4746 \pm 33$ & $5563-5318$ & $5562-5320$ & dwellrem & charcoal & \\
\hline \multicolumn{7}{|l|}{ Phase Pernil 1} \\
\hline \multicolumn{7}{|l|}{ Phase Layer 4043/4437 } \\
\hline Hd-28477 & $4784 \pm 33$ & $5575-5463$ & $5575-5462$ & layer & seeds & outlier \\
\hline ETH-38145 & $4821 \pm 27$ & & & & seeds & \\
\hline Hd-28786 & $4666 \pm 25$ & $5438-5289$ & $5321-5283$ & layer & charcoal & \\
\hline MAMS-13582 & $4625 \pm 24$ & $5432-5252$ & $5314-5278$ & layer & charcoal & \\
\hline Hd-30125 & $4661 \pm 25$ & $5436-5286$ & $5321-5282$ & layer & charcoal & \\
\hline Hd-30136 & $4646 \pm 25$ & $5433-5275$ & $5318-5281$ & dwellrem & charcoal & \\
\hline \multicolumn{7}{|l|}{ Phase Burials Dwelling 16} \\
\hline MAMS-13588 & $4637 \pm 32$ & $5434-5264$ & $5317-5279$ & burial & charcoal & \\
\hline MAMS-13587 & $4614 \pm 24$ & $5430-5240$ & $5311-5278$ & burial & charcoal & \\
\hline MAMS-13586 & $4982 \pm 24$ & $5724-5600$ & $5724-5600$ & burial & charcoal & outlier \\
\hline MAMS-13546 & $4671 \pm 24$ & $5439-5292$ & $5321-5284$ & burial & charcoal & \\
\hline \multicolumn{7}{|l|}{ Phase Burials Dwelling 02} \\
\hline Hd-26778 & $4614 \pm 57$ & $5439-5285$ & $5321-5282$ & burial & plant fibre & \\
\hline Hd-26688 & $4677 \pm 31$ & & & & bottle gourd & \\
\hline Hd-28636 & $4638 \pm 27$ & $5433-5267$ & $5316-5280$ & burial & vegetal & \\
\hline Hd-28590 & $4661 \pm 19$ & $5433-5290$ & $5320-5284$ & dwellrem & charcoal & \\
\hline MAMS- 13550 & $4617 \pm 24$ & $5430-5245$ & $5312-5278$ & pit & charcoal & \\
\hline \multicolumn{7}{|l|}{ Phase Burial Group Unit 6} \\
\hline MAMS-13579 & $4582 \pm 25$ & $5310-5059$ & $5309-5274$ & burial & charcoal & \\
\hline MAMS-13589-1 & $4618 \pm 25$ & $5431-5245$ & $5312-5278$ & burial & charcoal & \\
\hline \multicolumn{7}{|l|}{ Phase Pernil 2} \\
\hline MAMS-13553 & $4584 \pm 25$ & $5312-5060$ & $5293-5238$ & pit & charcoal & \\
\hline Hd-28784 & $4522 \pm 30$ & $5274-5029$ & $5288-5215$ & burial & charcoal & \\
\hline Hd-30133 & $4533 \pm 24$ & $5275-5043$ & $5286-5220$ & pit & wood & \\
\hline MAMS-13595 & $4481 \pm 27$ & $5248-4970$ & $5281-5202$ & burnzon & seeds & \\
\hline Hd-30090 & $4553 \pm 38$ & $5296-5036$ & $5292-5224$ & layer & charcoal & \\
\hline Hd-28508a & $4614 \pm 30$ & $5308-5249$ & $5295-5248$ & fireplace & seeds & \\
\hline Hd-28508b & $4595 \pm 25$ & & & fireplace & seeds & \\
\hline Hd-28589 & $4604 \pm 21$ & & & fireplace & charcoal & \\
\hline Hd-28588 & $4675 \pm 25$ & $5440-5295$ & $5441-5295$ & fireplace & charcoal & outlier \\
\hline MAMS-12417 & $4521 \pm 24$ & $5268-5036$ & $5285-5213$ & burial & bean & \\
\hline Hd-28468 & $4656 \pm 33$ & 5306-5239 & $5305-5239$ & burial & seeds & outlier \\
\hline ETH-38144 & $4669 \pm 27$ & & & & seeds & \\
\hline Hd-28795 & $4429 \pm 31$ & & & & wood & \\
\hline Hd-28678 & $4524 \pm 25$ & $5280-5046$ & $5284-5221$ & fireplace & charcoal & \\
\hline Hd-28478 & $4547 \pm 32$ & & & & seeds & \\
\hline ETH-38147 & $4543 \pm 26$ & & & & seeds & \\
\hline \multicolumn{7}{|l|}{ Phase Pernil 3} \\
\hline MAMS-13558 & $4546 \pm 24$ & $5287-5045$ & $5260-5074$ & dwellrem & charcoal & \\
\hline MAMS-13592 & $4508 \pm 25$ & $5264-5024$ & $5258-5085$ & post & wood & \\
\hline Hd-30124 & $4501 \pm 25$ & $5263-5014$ & $5258-5103$ & layer & charcoal & \\
\hline MAMS-13578 & $4587 \pm 24$ & $5313-5067$ & $5264-5070$ & burial & charcoal & \\
\hline
\end{tabular}




\begin{tabular}{|c|c|c|c|c|c|c|}
\hline Lab-Number / Assignment & 14C Age & calBP $2 \sigma$ & $\operatorname{modBP} 2 \sigma$ & feature type & material & comment \\
\hline \multicolumn{7}{|l|}{ Sequence Dwelling 12} \\
\hline MAMS-13548 & $4489 \pm 23$ & $5253-4992$ & $5258-5095$ & dwellrem & charcoal & \\
\hline MAMS-13545 & $4558 \pm 22$ & $5296-5049$ & $5256-5077$ & dwellrem & charcoal & \\
\hline \multicolumn{7}{|l|}{ Sequence Dwelling 07} \\
\hline Hd-28572 & $4480 \pm 17$ & $5239-4980$ & $5258-5115$ & dwellrem & charcoal & \\
\hline Hd-28679 & $4556 \pm 28$ & $5295-5045$ & $5255-5084$ & dwellrem & charcoal & \\
\hline \multicolumn{7}{|l|}{ Phase Pernil_4 } \\
\hline MAMS-13547 & $4507 \pm 22$ & $5260-5027$ & $5224-5039$ & burial & charcoal & \\
\hline MAMS-13555 & $4521 \pm 23$ & $5267-5037$ & $5225-5041$ & burial & charcoal & \\
\hline \multicolumn{7}{|l|}{ Sequence Dwelling 08} \\
\hline MAMS-13556 & $4518 \pm 25$ & $5267-5033$ & $5223-5041$ & dwellrem & charcoal & \\
\hline Hd-28774 & $4469 \pm 26$ & $5242-4955$ & $5217-5035$ & dwellrem & charcoal & \\
\hline \multicolumn{7}{|l|}{ Phase Layer $4038 / 4429$} \\
\hline Hd-28602 & $4474 \pm 25$ & $5243-4962$ & $5224-5030$ & layer & charcoal & \\
\hline Hd-28805 & $4495 \pm 24$ & $5259-5003$ & $5224-5035$ & layer & charcoal & \\
\hline Hd-30123 & $4518 \pm 25$ & $5267-5033$ & $5225-5040$ & layer & charcoal & \\
\hline MAMS-13562 & $4515 \pm 23$ & $5264-5033$ & $5225-5040$ & fireplace & charcoal & \\
\hline Hd-30126 & $4477 \pm 26$ & $5246-4966$ & $5224-5030$ & pit & charcoal & \\
\hline MAMS-13557 & $4464 \pm 25$ & $5241-4947$ & $5224-5025$ & dwellrem & charcoal & \\
\hline MAMS-13554 & $4459 \pm 25$ & $5240-4936$ & $5225-5022$ & burial & charcoal & \\
\hline \multicolumn{7}{|l|}{ Phase Pernil_5 } \\
\hline \multicolumn{7}{|l|}{ Phase Afteruse Dwelling 06} \\
\hline Hd-30101 & $4493 \pm 37$ & $5264-4969$ & $5199-4961$ & pit & charcoal & \\
\hline Hd-30102 & $4425 \pm 35$ & $5225-4843$ & 5204-4906 & burial & charcoal & \\
\hline MAMS-13538 & $4552 \pm 23$ & $5292-5046$ & $5292-5046$ & burial & charcoal & outlier \\
\hline MAMS-13551 & $4473 \pm 24$ & $5242-4962$ & $5200-4959$ & burial & charcoal & \\
\hline MAMS-13552 & $4681 \pm 24$ & $5443-5298$ & $5443-5298$ & burial & charcoal & outlier \\
\hline Hd-26779 & $4376 \pm 58$ & $5219-4801$ & $5203-4893$ & stonecon & charcoal & \\
\hline
\end{tabular}

\section{Economy}

During the excavation numerous plant remains were recovered in the form of seeds, fruits, stems, leaves and roots. Due to the generally arid conditions, these remains were very well-preserved. They can distinctly be separated into wild and domesticated plants ${ }^{37}$. Within the following calculation, only the edible parts of the food plants are incorporated, including seeds and fruits as well as roots in the case of the tubercles plants. Wild food plants are represented by the remains of huarango ${ }^{38}$ (Prosopis pallida) and Peruvian Pepper (Schinus molle). Cultivated food plants are represented by the remains of lima beans (Phaseolus lunatus), sweet potatoes (Ipomaea batatas), gourds (Cucurbita sp.), common beans (Phaseolus vulgaris), achira (Canna indica), jackbeans (Canavalia sp.) and guava (Psidium guajava). A single find, probably of remains of maize (Zea mays) in the form of a stem in a feature from phase 0 , is currently under review and is planned to be dated directly via AMS-dating. Regardless of the dating result, maize never played an important role in Pernil Alto, since it is represented by just one single find.
Furthermore, the remains of Pachyrrizhus sp. and Canna indica were found. These were determined as semi-wild, but were probably cultivated as well.

In addition to the remains of the mentioned food plants, non-food or industrial plant remains were recovered. They were mainly of not further determinable grass species, reed remains or tree remains. Of some importance are the remains of cultivated bottle gourds (Lagenaria siceraria) that were found in large quantities. This species was not used for alimentation purposes, but to produce vessels and thus was an industrial plant. The process of domestication is not visible in the plant remains of Pernil Alto.

If the weight portions of the remains of cultivated plants from Pernil Alto are compared with those of wild food plants, the proportion of cultivated plants clearly exceeds that of the wild food plants. The total weight of the above mentioned plant remains amounted to $1532 \mathrm{~g}^{39} .1111 \mathrm{~g}$ or $72.52 \%$ of that were the remains of cultivated plants and $421 \mathrm{~g}$ or $27.48 \%$ were the remains of wild food plants. The remains of bottle gourd (Lagenaria siceraria) constitute $617 \mathrm{~g}$ of the total remains. As this plant was 
an industrial plant, its importance for the estimation of the food economy of Pernil Alto is less important (Table 2 shows the weights and the ratios of the plant remains in total and separated into phases).

If exclusively food plants (leaving out the questionable Zea mays remains) were consequently considered, the ratio amounted to $493 \mathrm{~g}$ or $53.94 \%$ of cultivated plants in relation to $421 \mathrm{~g}$ or $46.96 \%$ of wild plants. The most important cultivated plants due to the weight of their remains were lima beans $(225.5 \mathrm{~g})$ and sweet potatoes $(204 \mathrm{~g})$ and huarango (416 g) was the most important plant among the wild plants. The remains of the other food plants that include the plants that were not doubtlessly determinable, such as Phaseolus cf. lunatus, Phaseolus sp., cf. Cucurbita and Prosopis sp./Acacia sp, totalled to just $69.5 \mathrm{~g}$.

These ratios make clear that the use of cultivated plants for the alimentation of the settlers of the Archaic occupation of Pernil Alto was not just supplementary within general plant use. They played an important role in the alimentation of the settlers.
Nevertheless, in addition to the consumption of plants there are some indications for hunting in the form of non-artefact faunal remains. These include the remains of camelids, cervids, rodents, birds, amphibians -that are not further determinable due to the preserved bone parts- as well as the remains of guinea pigs (Cavia sp. and Cavidae), deer (Odoicoelos virginianus), possibly fox and dog (Canidae, Canis), a frog (Betrachophrynus sp.) and 6 indeterminable individuals. The total minimum number of individuals (MNI) is just 69. If the remains of the 38 mammals (MNI) are considered exclusively, only the remains of 8 bigger mammals, including 2 camelids, 3 possible dogs, 1 possible fox, 1 deer and 1 not further determinable big mammal, were found. Among small mammals, 18 guinea pigs, 1 cavidae and 11 not further determinable rodents were identified.

If one includes the artefacts made of mammal bones, 21 big mammals, 1 camelid, 1 deer (Hippocamelus antisensis) and 2 whales have to be added to the group of represented mammals.

Table 2. The amounts of the plant remains of the Middle Archaic occupation. The second column indicates the total amount. The following columns indicate the amounts by phase. The final bold marked ratios represent the proportion between wild food plants and cultivated food plants. Within these ratios the amounts marked with "excl." were excluded. (* by the amount of the excluded plant remains (Lagenaria siceraria and Zea mays)

\begin{tabular}{|c|c|c|c|c|c|c|c|c|c|c|c|c|c|c|}
\hline \multirow{2}{*}{ Species } & \multicolumn{2}{|c|}{ Total } & \multicolumn{2}{|c|}{ Phase 0} & \multicolumn{2}{|c|}{ Phase 1} & \multicolumn{2}{|c|}{ Phase 2} & \multicolumn{2}{|c|}{ Phase 3} & \multicolumn{2}{|c|}{ Phase 4} & \multicolumn{2}{|c|}{ Phase 5} \\
\hline & gr. & $\%$ & gr. & $\%$ & gr. & $\%$ & gr. & $\%$ & gr. & $\%$ & gr. & $\%$ & gr. & $\%$ \\
\hline \multicolumn{15}{|l|}{ Cultivated } \\
\hline Phaseolus lunatus & 225.5 & 24.67 & 2.5 & 3.65 & 9 & 29.03 & 71.5 & 48.64 & 25 & 25.13 & 117.5 & 20.80 & 0 & 0.00 \\
\hline Phaseolus cf. lunatus & 10.5 & 1.15 & 7 & 10.22 & 2 & 6.45 & 0 & 0.00 & 1 & 1.01 & 0.5 & 0.09 & 0 & 0.00 \\
\hline Phaseolus vulgaris & 5.5 & 0.60 & 0 & 0.00 & 0 & 0.00 & 1.5 & 1.02 & 1 & 1.01 & 3 & 0.53 & 0 & 0.00 \\
\hline Phaseolus sp. & 2 & 0.22 & 0.5 & 0.73 & 0 & 0.00 & 1 & 0.68 & 0 & 0.00 & 0 & 0.00 & 0.5 & 16.67 \\
\hline Cannavalia sp. & 3 & 0.33 & 0 & 0.00 & 0 & 0.00 & 2 & 1.36 & 0 & 0.00 & 1 & 0.18 & 0 & 0.00 \\
\hline Ipomoea batatas & 204 & 22.32 & 10 & 14.6 & 0 & 0.00 & 18 & 12.24 & 27 & 27.14 & 149 & 26.37 & 0 & 0.00 \\
\hline Psidium guajava & 4.5 & 0.49 & 0 & 0.00 & 0.5 & 1.61 & 0 & 0.00 & 0 & 0.00 & 4 & 0.71 & 0 & 0.00 \\
\hline Cucurbita sp. & 10.5 & 1.15 & 5 & 7.3 & 1.5 & 4.84 & 0.5 & 0.34 & 0.5 & 0.50 & 3 & 0.53 & 0 & 0.00 \\
\hline cf. Cucurbita & 1 & 0.11 & 0 & 0.00 & 0 & 0.00 & 1 & 0.68 & 0 & 0.00 & 0 & 0.00 & 0 & 0.00 \\
\hline Pachyrrizhus sp. & 14.5 & 1.59 & 2 & 2.92 & 0 & 0.00 & 5.5 & 3.74 & 1 & 1.01 & 6 & 1.06 & 0 & 0.00 \\
\hline Canna indica & 12 & 1.31 & 0 & 0.00 & 0 & 0.00 & 0 & 0.00 & 0 & 0.00 & 12 & 2.12 & 0 & 0.00 \\
\hline Zea mays & 1 & excl. & 1 & excl. & 0 & excl. & 0 & excl. & 0 & excl. & 0 & excl. & 0 & excl. \\
\hline Lagenaria siceraria & 617 & excl. & 171.5 & excl. & 8 & excl. & 49.5 & excl. & 97.5 & excl. & 282 & excl. & 8.5 & excl. \\
\hline Wild & & & & & & & & & & & & & & \\
\hline Prosopis pallida & 416 & 45.51 & 39 & 56.93 & 17.5 & 56.45 & 45.5 & 30.95 & 44 & 44.22 & 268 & 47.43 & 2 & 66.67 \\
\hline Prosopis sp. /Acacia sp. & 2 & 0.22 & 1 & 1.46 & 0 & 0.00 & 0.5 & 0.34 & 0 & 0.00 & 0.5 & 0.09 & 0 & 0.00 \\
\hline Schinus molle & 3 & 0.33 & 1.5 & 2.19 & 0.5 & 1.61 & 0 & 0.00 & 0 & 0.00 & 0.5 & 0.09 & 0.5 & 16.67 \\
\hline \multicolumn{15}{|l|}{ Ratios } \\
\hline cultivated plants & 1111 & excl. & 199.5 & excl. & 21 & excl. & 150.5 & excl. & 152 & excl. & 579 & excl. & 9 & excl. \\
\hline wild plants & 421 & 46.06 & 41.5 & 60.58 & 18 & 58.06 & 46 & 31.29 & 44 & 44.22 & 269 & 47.61 & 2.5 & 83.33 \\
\hline total & 1532 & excl. & 241 & excl. & 39 & excl. & 196.5 & excl. & 197 & excl. & 847 & excl. & 11.5 & excl. \\
\hline $\begin{array}{l}\text { cultivated plants } \\
\text { reduced } *\end{array}$ & 493 & 53.94 & 27 & 39.42 & 13 & 41.94 & 101 & 68.71 & 55.5 & 55.78 & 296 & 52.39 & 0.5 & 16.67 \\
\hline total reduced* & 914 & 100 & 68.5 & 100 & 31 & 100 & 147 & 100 & 99.5 & 100 & 565 & 100 & 3 & 100 \\
\hline
\end{tabular}


But animal remains in the form of artefacts do not necessarily represent the results of single hunting events and their inclusion might therefore be misleading. This is obviously the case for the 2 whales that are represented in the form of pendants made of whale teeth excavated from two burials. They probably do not represent the result of a whale hunt on the Pacific Ocean, but were rather taken from stranded whales on the beach. Furthermore, bone artefacts could have had their origin in exchange processes with hunting groups or could represent fewer individual animals, since the bones of the same individual could have been used as tools or jewellery and were then distributed to different features.

In total, the faunal remains do not show very intense hunting activities in Pernil Alto. Other sites in the highlands, such as Asana ${ }^{40}$, Uchkumachay ${ }^{41}$ or even the Guitarrero Cave ${ }^{42}$, yielded distinctly more faunal remains (especially from big mammals), although they were very fragmented in some cases. Thus, it can be estimated that hunting in Pernil Alto was not as important as could be expected from a typical "hunting site". This activity was probably of supportive character for alimentation that was already based on cultivated and collected plants, an assumption also supported by just two obsidian projectile point artefacts and one spear-thrower head made of bone, indicating hunting activities. In comparison with the numerous ground- and handstones, their occurrence is very minimal.

As outlined above, the Middle Archaic occupation of Pernil Alto can be subdivided into six phases. Examining the distribution of the ratios of the use of collected and cultivated food plants some differences appear. During the first phase (phase 0) the proportion of cultivated plants, as the weight of all food plant remains of this phase $(68.5 \mathrm{~g})$, amounted to just $39.42 \%$. It increased slightly towards $41.94 \%$ (of $31 \mathrm{~g}$ ) during phase 1 . The highest proportion of cultivated plants among all food plants was reached during phase 2 with $68.71 \%$ (of $147 \mathrm{~g}$ ). This proportion decreases in phase 3 to $55.78 \%$ (of $99.5 \mathrm{~g}$ ) and to $52.39 \%$ (of $565 \mathrm{~g}$ ) in phase 4 . Just $3 \mathrm{~g}$ of food plant remains were found in phase 5 , which is too low to incorporate it into further considerations.

Thus, during phase 0 cultivated plants were less important for the alimentation than collected plants. This also corresponds to the fact that one of the two obsidian projectile points and the spear thrower date to this phase. Horticulture was already conducted within this phase, but foraging was still more important. During phase 1 , horticulture increased in importance, but was still less important than collecting. From phase 2 onwards, horticulture became more important in the economy and exceeded plant collecting. From that phase on, produced food formed the basis of alimentation. But a distinct decreasing trend is recognizable from the peak of cultivated plant use in phases 2 until phase 4 .

In total, Pernil Alto was a horticultural settlement consisting of small arranged huts that were later used to embed burials. The artefact composition displays the entire activity range of a settlement. Thus, Pernil Alto can be interpreted as a sedentary settlement in the form of a village. Nevertheless, some less pronounced connections with the highlands are visible in the form of obsidian artefacts, and distinct connections to the littoral are represented by the shell artefacts. Thus, a certain probability could not be precluded that the assemblage may have been the result of non-continuous reoccupations during some months of a year. But the occupation layers that are connected with the Middle Archaic occupation are few and thick in the central part of the site, even though parts of them were destroyed by the later occupation of the Initial Period and erosion. Furthermore, some Strontium(Sr)-isotope-analyses were conducted on the skeleton remains of the individuals to identify if the measured $\mathrm{Sr}$-ratios of the individuals reflect the natural Sr-ratios of the surroundings of the site $^{43}$. The results indicate that the population used the resources of the surroundings. The artefacts found at the site that originate from other regions are probably the results of some infrequent forays into the highlands -in the case of the obsidian-and some stronger connections to the littoral as the shell beads indicate. The latter artefacts may have been the result of some exchange with other groups located on the littoral.

Thus, Pernil Alto represents a permanent sedentary site with an economy that can be subscribed as "horticultural with additional foraging". This is an important step in the development that led to established agriculture in the Central Andes and later formed the basis for complex societies. It is furthermore significant that a site like this was located inland on the Andean piedmont and not on the Pacific littoral, where marine resources still exceeded the use of cultivated plants. 


\section{Palaeo-climatic situation and palaeo- landscape reconstruction}

The questions raised here now inquire under which climatic conditions a permanent settlement independent from the coastal resources could develop and if those conditions could have influenced this development?

Currently, the landscape around Pernil Alto is one of the driest in the world. Local precipitation amounts only to $5.1 \mathrm{~mm} / \mathrm{a}^{44}$. Nevertheless, the area is agriculturally very productive. This productivity is restricted to the fertile valleys of rivers that cross the desert plain from the highlands towards the coast. The catchments of the rivers are located within the highland areas, where rainfalls originating from the Amazon basin converge ${ }^{45}$. Nevertheless, just the Río Grande River -the main river of the Río Grande Basin in which all other rivers of the basin disembogue- is perennial, as its catchment is located far enough to the east and thus fed even during the dry season by rainfalls. The water of the rivers is currently used in a complex and well organized irrigation system to make nearly year round agriculture possible. The fertile alluvial sediments in the river beds form the basis of this desert agriculture. These sediments are or were brought there by flooding events. An additional feature contributing to the productivity of the South Peruvian coastal desert is the coastal mountain range (cordillera de la costa) that reaches up to $1500 \mathrm{~m}$ a.s.l. and blocks the fog that hits the Peruvian coast during the austral winter and covers the coastal plains of Northern and Central Peru for months. Thus, in the longitudes of the Southern Peruvian coastal plain fronted by the coastal mountains 350-360 days of the year are sunny with a daily average of 7.4 hours of sunshine, whereas north of it sunshine averages to just 1.76 hours a day ${ }^{46}$.

Starting from Pernil Alto, different current ecological zones are located within specific distances. In general, vegetation increases very slightly towards the east, which is at the same time an increase in altitude. B. Mächtle ${ }^{47}$ distinguished three cactizones that are located vertically in three succeeding altitude levels. The first zone begins at about $700 \mathrm{~m}$ a.s.l., thus close to Pernil Alto. However, the vegetation in these cacti-zones is, in general, extremely sparse and composed of cacti and small shrubs and grasses at higher altitudes. Towards the west outside the river valleys there is no vegetation at all. The ONERN ${ }^{48}$ reported some lomas (coastal seasonal fog oasis) close to the estuary of the Río Grande in the 1960s. These lomas do not exist any longer and it is impossible to make them visible via colour-exaggeration on Landsat-pictures ${ }^{49}$. Thus, Pernil Alto is situated in a desert area with a very slight vegetation increase towards the east and with rivers that give rise to fertile river oases.

B. Eitel et al..$^{50}$ discovered loess sedimentation in the area of Palpa. This loess was palaeo-accumulated and had to be fixed originally by a grass cover that is typical for loess accumulations. This grass cover was proved by phytoliths and remains of distinct snail species which were recovered from the loess deposits $^{51}$. Based on several samples and datings of the loess cover, it was possible to reconstruct palaeoclimatic variations in the area of $\mathrm{Palpa}^{52}$. The palaeoclimate during the Archaic Period was thereby reconstructed as having been "semi-arid", with an estimated mean annual precipitation of $>200 \mathrm{~mm} /$ $\mathrm{a}^{53}$. The landscape was characterized -based on the loess that was accumulated-as "open grassland" 54 . Thus, climatic conditions during the Middle Archaic occupation of Pernil Alto were far more favourable than today.

As precipitation originates east of the area around Pernil Alto -which corresponds with an increasing altitude in the same direction- and precipitation was higher during the Middle Archaic Period, vegetation in the landscape of the Middle Archaic Period probably reached farther westward and into lower altitudes than today. Loess that indicates grass vegetation accumulated in patches at altitudes of 450-1200 m a.s.1. ${ }^{55}$. At altitudes between 1200 and $1700 \mathrm{~m}$ a.s.l. it was accumulated densely and continuously ${ }^{56}$. Above $1700 \mathrm{~m}$ a.s.l. and up to $2200 \mathrm{~m}$ a.s.l. it accumulated less densely and mixed with other sediments or was covered by pedogenesis ${ }^{57}$. If this altitudinal distribution of loess is taken as a basis for a palaeo-landscape reconstruction and taking into account that precipitation increased with increasing altitude/east, then different ecological zones can be estimated during the Middle Archaic Period in the longitude of Pernil Alto between the Pacific littoral and the higher zones of the Andes Mountains (Figure 8).

The area around and east of Pernil Alto was covered by a sparse grass steppe that is indicated by the distribution of the loess accumulated in patches at altitudes of 450-1200 $\mathrm{m}$ a.s.l. These patches were not necessarily the result of an uncontinuous accumulation, 


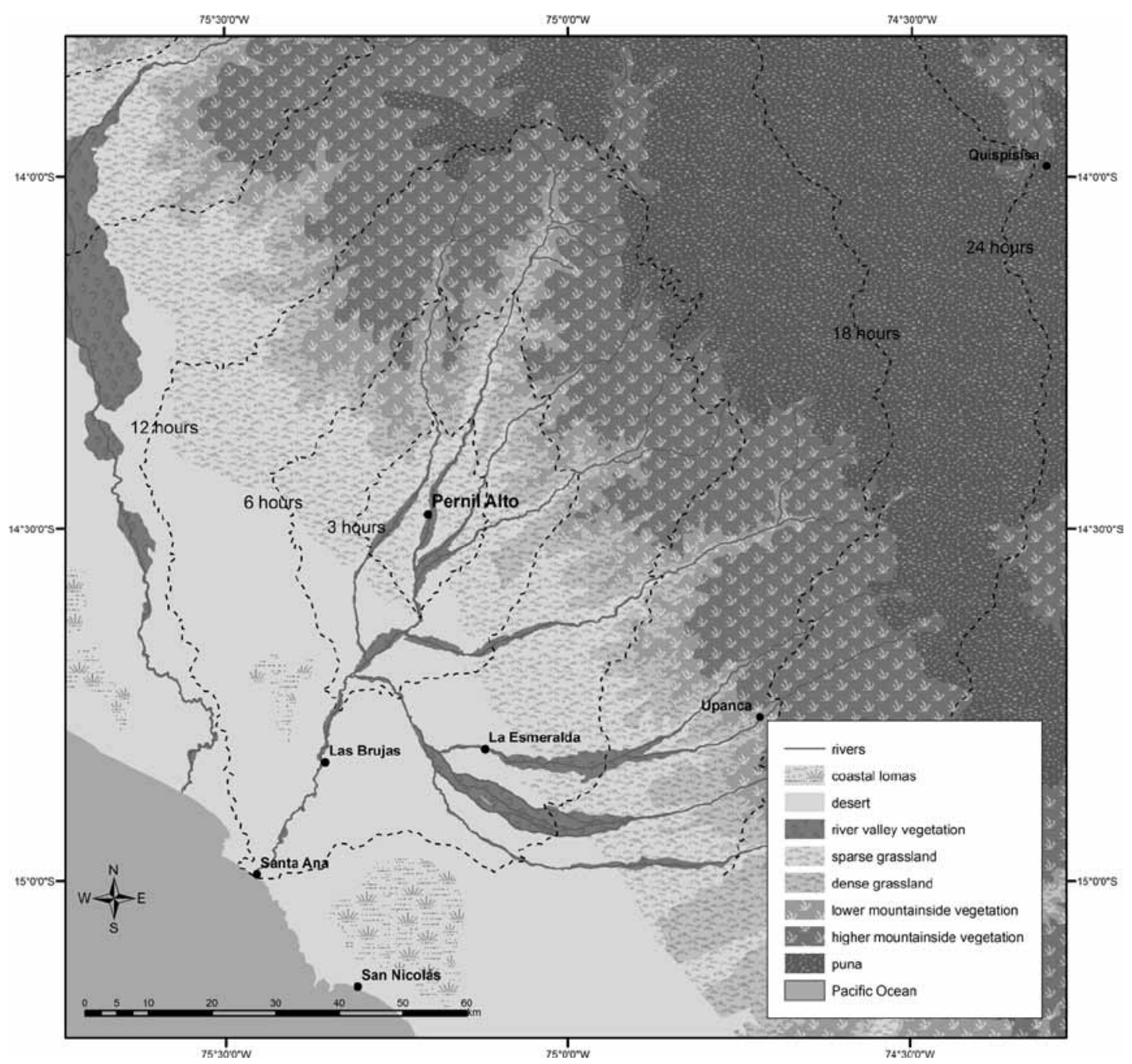

Figure 8. Map showing the location of Pernil Alto in the reconstructed landscape during the occupation of the site. The other known Archaic sites of the Rio Grande basin and Quispissisa are depicted. The dotted lines indicate areas reachable within a certain time.

but rather resulted from a less dense accumulation that was more strongly affected by erosion and thus remained in patches ${ }^{58}$. This (at least) sparse grassland could have been the natural habitat of cervids. East of that sparse grassland, at altitudes of $1200-1700 \mathrm{~m}$ a.s.l., dense grassland can be assumed, indicated by the dense loess cover. Between 1700 and 2200 m a.s.l., a lower mountainside vegetation can be estimated as more precipitation fell there, maybe in the form of bushes with open areas of grass in which the loess was partly accumulated, but where higher precipitation already led to pedogenesis. Above $2200 \mathrm{~m}$ a.s.l., higher mountainside vegetation was probably even denser as more precipitation fell, but the lack of loess accumulation indicated no grassland. Beginning at about $3800 \mathrm{~m}$ a.s.l., the highland puna can be estimated to have had more or less the same distribution as today, as the wind regime and temperatures probably did not permit another vegetation type.

No loess accumulation was registered to the west of Pernil Alto and an arid desert comparable to the current situation can be estimated ${ }^{59}$. The sea surface temperatures of the Pacific Ocean in front of the Río Grande Basin were reconstructed to have been about $0.7^{\circ} \mathrm{C}$ colder than today ${ }^{60}$. Thus, rich marine resources depending on the cold Humboldt upwelling water can be estimated on the littoral. As higher precipitation rates fed the highland river catchments, the river valley vegetation in the form of riparian forests and huarango (Prosopis pallida) 
stands was probably much denser than today. Those trees were probably not cleared on a large scale during the Middle Archaic Period. Furthermore, the close river banks were probably wetter in general and flooding events more frequent making the river banks more suitable for non-irrigation-based planting. Close to the coast, lomas can be at assumed at least in their last mapped extension ${ }^{61}$. Lomas attract guanacos which dismount during the flowering periods of the lomas reaching them by following the rivers ${ }^{62}$.

Within this reconstruction Pernil Alto was -in great contrast to the current situation- situated in a very favourable surrounding. The fertile river banks of the Río Grande were directly accessible from the site. Fields or gardens were possibly located in the area of an ancient river meander south of the spur of the site that offered humid and fertile land. The cultivation of lima beans and sweet potatoes can be assumed there. The riparian forest and the huarango vegetation offered possibilities for intense collection that is demonstrated by the huarango remains at the site. Within a distance of three hours by foot $^{63}$, grass land was accessible that is the natural habitat of cervids and during the flowering period of the lomas guanacos that passed the site can be assumed. Both -cervids and guanacos- were hunted animals, although not to a great extent. The littoral of the Pacific Ocean, in contrast, was reachable within about 12 hours of (exclusive) walking, making it an intense one-day or a regular two-day trip. The puna in the east was reachable in more or less the same time, but the area of Quispisisa, the probable origin of the obsidian found in Pernil Alto, was at a distance of more than 24 walking hours.

Thus, the earliest permanent horticultural settlement of Southern Peru known so far did not develop in a landscape situation that could be described as critical or hard, producing pressure to change the way of life of the inhabitants. The opposite is the case: The earliest horticulture developed -according to landscape reconstruction and information on the Middle Archaic occupation of Pernil Alto- under very favourable conditions when compared to today's situation. Thus, the outset of this new economy was more an opportunity embraced, rather than a provoked reaction.

The above outlined diachronic changes in the ratios of the used food plants could furthermore reflect short scale climatic variations. There are a number of possible scenarios to explain such a trend. Phase
0 is very time-spanning, but in general a stepwise economical change towards horticulture seems to be visible. The decreasing trend, on the other hand, could have had different reasons. Cultural decisions, conflicts, epidemics etc. could have played a role. There is no information available on that. Conversely, it is clear that climatic conditions could affect the yield of a harvest. Thus, a climatic micro-trend is possibly visible within the plant ratios of Pernil Alto. Climatic micro-trends are difficult to react to in horticultural economies without established techniques, such as irrigation, so that a reaction could have been to conduct more collecting and foraging. Thus, the other one of the two obsidian projectile points found in Pernil Alto dates to phase 4. Nevertheless, these ideas can be nothing more than assumptions that have to be proven by further palaeoclimatic and archaeological research.

\section{Palaeoclimatic situation during the Middle Archaic Period in the Central Andes}

The favourable situation of the Middle Archaic Period in the area of Pernil Alto cannot be extrapolated to the entire Central Andes region. In contrast to the area around Palpa, there are records of more arid or less favourable climatic conditions than today from other areas.

Thus, Lake Titicaca had a low water level during the mid-Holocene, indicating more arid conditions than today ${ }^{64}$. Comparable conditions were reconstructed for lakes in the Northern Chile Altiplano $^{65}$. In the area between Lake Titicaca and the Northern Chile Altiplano, the investigation of ice-cores showed warmer and more arid conditions than today in the Bolivian Altiplano ${ }^{66}$.

On the other hand, there are indications for more humid conditions than today in other parts of the Central Andes. The Northern Central Atacama desert in Chile showed more humid conditions than today between 8000 and $3000 \mathrm{BP}^{67}$. From the Quebrada de los Burros site on the Southern Peruvian coast more humid conditions are reported between about 8000 and 3300 cal BP ${ }^{68}$. Until 2800 cal BP, the area near Arequipa was more humid than it is today ${ }^{69}$. Multiproxy studies from the Laguna Acuelo in Central Chile indicate a trend towards more humidity between 5700 and $3200 \mathrm{cal} \mathrm{BP}{ }^{70}$. Lake Aricota in Southern Peru reached a high water level between 6100 and $2700 \mathrm{cal}$ BP, indicating wetter conditions than today as well ${ }^{71}$. 
The differences between areas with more arid or more humid microclimates than today could be explained, at least in part, by a possible shift of the Bolivian High that may have impacted moisture transport in the Central Andes during the mid-Holocene ${ }^{72}$. However, it appears that the palaeoclimate during the Middle Archaic Period was not wetter or drier across the entire Central Andes, but that there was a coexistence of different microclimatic areas. Furthermore, the onset of the El Niño Southern Oscillation (ENSO) phenomenon can be dated to about $5800 \mathrm{BP}^{73}$.

Therefore, the Middle Archaic occupation of Pernil Alto was situated in favourable conditions, but at the same time other areas -more or less close by- showed very unfavourable conditions. This situation probably produced a "push and pull" mechanism ${ }^{74}$. Human groups in areas with less favourable conditions were rather "forced" to leave those areas, although entire populations did not need to be "pushed out" of those less favourable areas. In contrast, the more favourable areas were probably more attractive to human groups. These landscapes had a "pulling effect". Within the favourable areas, human groups could apply techniques that they had already developed -the cultivation of plants- but never implemented with a status of higher importance. This scenario fits well to the considerations of human-environmental-interactions by B. Eitel ${ }^{75}$ in which both aspects -human decision mechanisms and environmental conditions- are interrelated factors of cultural development in the sense of change.
Nevertheless, the idea of an interplay between "pushing" and "pulling" landscapes within the process of beginning agriculture in the Central Andes needs more archaeological and palaeoenvironmental research.

\section{Conclusion}

Pernil Alto was a permanent settlement with an economy based on horticulture with additional foraging. The techniques of this new economy in Southern Peru were invented elsewhere. Domesticated food plants were already known. But the establishment of the new economy using those techniques was new. It took place in an "off-shore" area, some $60 \mathrm{~km}$ inland, so that marine resources were rather unimportant. Furthermore, it took place under favourable conditions and thus was rather the embracement of an opportunity and not a reaction to environmental pressure. The development might have been caused or intensified by the coexistence of more favourable and less favourable landscapes in different microclimatic areas in the Central Andes. In order to clarify this assumption, further research is necessary that concentrates more on the Andean piedmont than on the littoral or the highlands.

\section{Acknowledgments}

I wish to thank the organizers of the session during the conference and to Markus Reindel and Eileen Kücükkaraca for critically reviewing the manuscript and correcting the grammar.

\section{References Cited}

\footnotetext{
Aldenderfer, M.S.

1998 Montane Foragers. Asana and the south-central Andean archaic. Iowa City.

Benfer, R.A.

1990 The Preceramic Period Site of Paloma, Peru: Bioindications of Improving Adaption to Sedentism. Latin American Antiquity 1, 284-318.

Beresford-Jones, D.G.

2004 Pre-Hispanic Prosopis-Human Relationships on the South Coast of Peru: Riparian Forests in the Context of Environmental and Cultural Trajectories of the Lower Ica Valley. Dissertation, University of Cambridge, Cambridge.

Betancourt, J.L.; C. Latorre; J.A. Rech; J. Quade y K.A. Rylander 2000 A 22,000-Year Record of Monsoonal Precipitation from Northern Chile's Atacama Desert. Science 289, 1542-1546.

Bird, J.B. y J. Hyslop

1985 The preceramic excavations at the Huaca Prieta. Chicama Valley, Peru. Anthropological papers of the American museum of natural history. Vol. 62. New York.
}

Bronk Ramsey, C.

1995 Radiocarbon Calibration and Analysis of Stratigraphy: The OxCal Program. Radiocarbon 37, 425-430.

2009 Bayesian analysis of radiocarbon dates. Radiocarbon 51, 337-360.

Burger, R.L. y M.D. Glascock

2000 Locating the Quispisisa Obsidian Source in the Department of Ayacucho. Latin American Antiquity 11, 258-268.

Carré, M.; I. Bentaleb; M. Fontugne y D. Lavallée

2005 Strong El Niño events during the early Holocene: stable isotope evidence from Peruvian sea shells. The Holocene 15, 42-47.

Cross, S.; P. Baker; G. Seltzer; S. Fritz y R. Dunbar

2000 A new estimate of the Holocene lowstand level of Lake Titicaca, central Andes, and implications for tropical palaeohydrology. The Holocene 10, 21-32.

Dillehay, T.D. y K. Stackelbeck

2011 Tierra Blanca Phase (7800-5000 BP). In: From foraging to farming in the Andes: New Perspectives on Food 
Production and Social Organization. T. D. Dillehay (ed.). New York, 117-134.

Dillehay, T.D.; D. Bonavia; S. Goodbred; M. Pino; V. Vasquez; T.R. Tham; W. Conklin; J. Splitstoser; D. Piperno; J. Iriarte; A. Grobman; G. Levi-Lazzaris; D. Moreira; M. Lopéz; T. Tung; A. Titelbaum; J. Verano; J. Adovasio; L. Scott Cummings; P. Bearéz; E. Dufour; O. Tombret; M. Ramirez; R. Beavins; L. DeSantis; I. Rey; P. Mink; G. Maggard y T. Franco

2012 Chronology, mound-building and environment at Huaca Prieta, coastal Peru, from 13700 to 4000 years ago. Antiquity 86, 48-70.

Donnan, C.B.

1964 An Early House from Chilca, Peru. American Antiquity 30, 137-144.

Eitel, B.

2007 Kulturentwicklung am Wüstenrand -: Aridisierung als Anstoß für frühgeschichtliche Innovation und Migration. In: Einführung in die Archäometrie. G.A. Wagner (ed.). Berlin, Heidelberg, 301-319.

Eitel, B. y B. Mächtle

2008 Man and Environment in the Eastern Atacama Desert (Southern Peru): Holocene Climate Changes and Their Impact on Pre-Columbian Cultures. In: New Technologies for Archaeology: Multidisciplinary Investigations in Palpa and Nasca, Peru. M. Reindel y G.A. Wagner (eds.). Berlin; Heidelberg, 17-37.

Eitel, B.; S. Hecht; B. Mächtle; G. Schukraft; A. Kadereit; G.A. Wagner; B. Kromer; I. Unkel y M. Reindel

2005 Geoarchaeological evidence from desert loess in the Nazca-Palpa region, Southern Peru: palaeoenvironmental changes and their impact on pre-Columbian cultures: Palaeoenvironmental changes and their impact on pre-columbian cultures. Archaeometry 47, 137-158.

Engel, F.A.

1980 Paloma Village 613: A 6,000 Year Old "Fog Oasis" Village in the Lower Central Andes of Peru. In: Prehistoric Andean ecology: Man, settlement and environment in the Andes. F.-A. Engel (ed.). Atlantic Highlands, N.J., 103-135. 1987 De las begonias al maíz. Vida y producción en el Perú antiguo. Lima.

1988 Ecología prehistórica andina. El hombre, su establecimiento y el ambiente de los Andes, la vida en tierras áridas y semiáridas. Chilca, Pueblo 1. Implementos de hueso. Lima. 1981 Prehistoric Andean ecology. Man, settlement and environment in the Andes. The deep south. New York.

Everett, S.L.

1966 A theory of migration. Demopgraphy 3, 47-57.

Flannery, K.V.

1973 The Origins of Agriculture. Annual Review of Anthropology 2, 271-310.

Fontugne, M.; P. Usselmann; D. Lavallée; M. Julien y C. Hatté 1999 El Niño Variability in the Coastal Desert of Southern Peru during the Mid-Holocene. Quaternary Research 52, 171-179.

Fuchs, P.R.; R. Patzschke; C. Schmitz; G. Yenque y J. Briceño 2006 Investigaciones arqueológicas en el sitio de Sechín Bajo, Casma. In: Procesos y expresiones de poder, identidad y orden tempranos en Sudamérica: Primera parte. 111-135. P. Kaulicke y T.D. Dillehay (eds.), PUCP 10. Lima.

Holmgren, C.A.; J.L. Betancourt; K.A. Rylander; J. Roque; O. Tovar; H. Zeballos; E. Linares y J. Quade

2001 Holocene Vegetation History from Fossil Rodent Middens near Arequipa, Peru. Quaternary Research 56, 242-251.
Horkheimer, $\mathrm{H}$.

1960 Nahrung und Nahrungsgewinnung im vorspanischen Peru. Bibliotheca Ibero-Americana. Vol. 2. Berlin.

Isla Cuadrado, J.

1990 La Esmeralda: Una ocupación del Período Arcaico en Cahuachi, Nasca. Gaceta Arqueológica Andina 5, 67-80.

2008 From Hunters to Regional Lords: Funerary Practices in Palpa, Peru. In: New Technologies for Archaeology: Multidisciplinary Investigations in Palpa and Nasca, Peru. M. Reindel y G.A. Wagner (eds.). Berlin; Heidelberg, 119-139.

Jenny, B.; B.L. Valero-Gracés; R. Urrutia; M. Geyh y H. Veit 2002 Early to Mid-Holocene Aridity in Central Chile and the Southern Westerlies: The Laguna Aculeo Record (34S). Quaternary Research 58, 160-170.

Kaplan, L. y T.F. Lynch

1999 Phaseolus (Fabaceae) in Archaeology: AMS Radiocarbon Dates and their Significance for Pre-Columbian Agriculture. Economic Botany 53, 261-272.

Kaulicke, $\mathrm{P}$.

1980 Der Abri Uchkumachay und seine zeitliche Stellung innerhalb der lithischen Perioden Perus. Beiträge zur Allgemeinen und Vergleichenden Archäologie 2, 429-458.

Lavallée, D.; M. Julien; J. Wheeler y C. Karlin

1985 Telarmachay: . Chasseurs et Pasteurs Préhistoriques des Andes. Editions Recherche sur les Civilisations, Synthèse. Vol. 20. Paris

Lynch, T.F.

1980a Review on Rick 1980, Prehistoric Hunters of the High Andes. Science 209, 488-489.

Mächtle, B.

2007 Geomorphologisch-bodenkundliche Untersuchungen zur Rekonstruktion der holozänen Umweltgeschichte in der nördlichen Atacama im Raum Palpa, Südperu. Heidelberger Geographische Arbeiten. Vol. 123. Heidelberg.

Mächtle, B.; I. Unkel; B. Eitel; B. Kromer y S. Schiegl

2010 Molluscs as evidence for a late Pleistocene and early Holocene humid period in the southern coastal desert of Peru (14.5 S). Quaternary Research 73, 39-47.

McCormac, F.G.; P.J. Reimer; A.G. Hogg; T.F.G. Higham, Baillie M.G.L.; J. Palmer y M. Stuiver

2002 Calibration of the Radiocarbon Time Scale for the Southern Hemisphere: AD 1850-950. Radiocarbon 44, 641-651.

Moseley, M.E.

1973 Aspero, Peru: A Reexamination of the site and Its implications. American Antiquity 38, 452-468.

Oficina Nacional de Evaluación de Recursos Naturales (ONERN) 1971 Inventario, evaluación y uso racional de los recursos naturales de la costa. Cuenca del Río Grande (Nazca). Volumen I: Informe. Lima.

Oficina Nacional de Evaluación de Recursos Naturales (ONERN) 1976 Mapa ecológico del Perú.

Palomino, I.V.

2006 Report only relict population of the Peruvian Guanaco (Lama Guanicoe) left in the coastal desert of Las Lomas de San Fernando, Department of Ica - 2003. In: IV Congreso Mundial sobre Camélidos: Resúmenes y trabajos. M. Miragaya, D. Olivera y S. Puig (eds.), 1-4. IV Congreso Mundial sobre Camélidos, Santa María. 11.-15.10.2006. Buenos Aires.

Pearsall, D.M.

1999 Agricultural Evolution and the Emergence of Formative Societies in Ecuador. In: Pacific Latin America in Prehistory: The Evolution of Archaic and Formative Cultures. M. Blake (ed.). Pullman, 161-170. 
Placzek, C.; J. Quade y J.L. Betancourt

2001 Holocene lake-level fluctuations of Lake Aricota, Southern Peru. Quaternary Research 56, 181-190.

MacNeish, R.S.; A.G. Cook; L.G. Lumbreras; R.K. Vierra y

A. Nelken-Terner (eds.)

1981 Prehistory of the Ayacucho Basin, Peru. Volume

II: Excavations and Chronology. Ann Arbor.

MacNeish, R.S.; R.K. Vierra; A. Nelken-Terner y C.J. Phagan (eds.)

1980 Prehistory of the Ayacucho Basin, Peru. Volume

III: Nonceramic Artifacts. Ann Arbor.

MacNeish, R.S.; R.K. Vierra; A. Nelken-Terner; R. Lurie y

A.G. Cook (eds.)

1983 Prehistory of the Ayacucho Basin, Peru. Volume IV: The Preceramic Way of Life. Ann Arbor.

Reimer, P.J.; M. Baillie; E. Bard; A. Bayliss; J. W. Beck; P.G. Blackwell; C.B. Ramsey; C.E. Buck; G.S. Burr; R.L. Edwards; M. Friedrich; P.M. Grootes; T.P. Guilderson; I. Hajas; T.J. Heaton; A.G. Hogg; K.A. Hughen; K.F. Kaiser; B. Kromer; G. McCromac; S.W. Manning; R.W. Reimer; D. A. Richards; J.R. Southon;

S. Talamo; C.S.M. Turney; J. van der Pflicht y C.E. Weyhenmeyer 2009 IntCa109 and Marine09 radiocarbon age calibration curves, 0-50,000 years cal BP. Radiocarbon 51, 1111-1150.

Reindel, M.

2008 Life at the Edge of the Desert -: Archaeological Reconstruction of the Settlement History in the Valleys of Palpa, Peru. In: New Technologies for Archaeology: Multidisciplinary Investigations in Palpa and Nasca, Peru. M. Reindel y G. A. Wagner (eds.). Berlin; Heidelberg, 439-461.

Reindel, M. y J. Isla Cuadrado

2006 Evidencias de culturas tempranas en los valles de Palpa, costa sur del Perú. In: Procesos y expresiones de poder, identidad y orden tempranos en Sudamérica: Primera parte. P. Kaulicke y T. D. Dillehay (eds.), PUCP 10. Lima, 237-283.

Rick, J.W.

1980 Prehistoric Hunters of the High Andes. New York.

Rick, J.W. y K.M. Moore

1999 El precerámico de la puna de Junín: El punto de vista desde Panaulauca. In: El periodo arcaico en el Perú: Hacia una definición de los orígenes. P. Kaulicke (ed.), PUCP 3. Lima, 263-296.

Rowe, H.D.; R.B. Dunbar; D.A. Mucciarone; G.O. Seltzer; P.A. Baker y S. Fritz

2002 Insolation, Moisture Balance and Climate Change on the South American Altiplano Since the Last Glacial Maximum. Climatic Change 52, 175-199.

Sandweiss, D.H.; K.A. Maasch; C.F.T. Andrus; E.J. Reitz;

J.B. [. Richardson; M. Riedinger-Whitmore y H.B. Rollins

2007 Mid-Holocene climate and culture change in coastal Peru. In: Climate change and cultural dynamics: A global perspective on mid-Holocene transitions. D. G. Anderson, K. A. Maasch y D. H. Sandweiss (eds.). New York, 25-50.

Schwalb, A.; S.J. Burns y K. Kelts

1999 Holocene environments from stable isotope stratigraphy of ostracods and authigenic carbonate in Chilean Altiplano Lakes. Palaeogeography, Palaeoclimatology, Palaeoecology 148, 153-168.

Shady Solís, R.

1999 Los orígenes de la civilización y la formación del Estado en el Perú: Las Evidencias Arqueológicas de CaralSupe. Primera Parte. Boletín del Museo de Arqueología y Antropología de la UNMSM 2, 2-4.
2000 Los orígenes de la civilización y la formación del Estado en el Perú: Las Evidencias Arqueológicas de CaralSupe. Segunda Parte. Boletín del Museo de Arqueología y Antropología de la UNMSM 3, 2-7.

Shady Solís, R.; J. Haas y W. Creamer

2001 Dating Caral, a Preceramic Site in the Supe Valley on the Central Coast of Peru. Science 292.

Shady Solís, R. y C. Leyva (eds.)

2003 La cuidad sagrada de Caral-Supe. Los orígenes de la civilización andina y la formación del Estado prístino en el antiguo Perú. Lima.

Shady Solís, R.; M. Machacuay Romero; D. Cáceda Guillén;

A. Crispín Balta y E. Quispe Loayza

2009 Caral, the Oldest Civilization in the Americas: 15 years unveiling its history. Lima.

Stothert, K.E.

1985 The Preceramic Las Vegas Culture of Coastal Ecuador. American Antiquity 50, 613-637.

Strong, W.D.

1957 Paracas, Nazca, and Tiahuanacoid Cultural Relationships in South Coastal Peru. Memoirs of the Society for American Archaeology. Vol. 13. Salt Lake City.

Lynch, T.F., (ed.)

1980b Guitarrero Cave. Early man in the Andes. Studies in Archaeology. Vol. 1. New York.

Thompson, L.G.; M.E. Davis; E. Mosley-Thompson; T.A. Sowers; K.A. Henderson; V.S. Zagorodnov; P.-N. Lin; V.N. Mikhalenko; R.K. Campen; J.F. Bolzan; J. Cole-Dai y B. Francou 1998 A 25,000-Year Tropical Climate History from Bolivian Ice Cores. Science 282, 1858-1864.

Tobler, W.R.

1961 Map Transformations of Geographic space. Dissertation, University of Washington, Seattle.

Usselmann, P.; M. Fontugne; D. Lavallée; M. Julien y C. Hatté 1999 Estabilidad y rupturas dinámicas en el Holoceno de la costa sur peruana: El valle de la quebrada de los Burros (Departamento de Tacna). Bulletin de l'Institut Français d'Études Andines 28, 1-11.

Vaughn, K.J. y M. Linares Grados

2006 3,000 Years of Occupation in Upper Valley Nasca: Excavations at Upanca. Latin American Antiquity 17, 595-612.

Vogt, B.

2011 Las Brujas, Bajo Río Grande (Perú). In: Jahresbericht 2010. Vol. 1. Deutsches Archäologisches Institut (ed.), 307-308.

Wheeler Pires-Ferreira, J.; E. Pires-Ferrera y P. Kaulicke 1976 Preceramic Animal Utilization in the Central Peruvian Andes: Uchcumachay Cave faunal remains document the process of camelid domestication in the Puna of Junin. Science 194, 483-490.

Wing, E.S.

1980 Faunal Remains. In: Guitarrero Cave: Early man in the Andes. T. F. Lynch (ed.). Studies in Archaeology, vol. 1. New York, 149-172.

Wirrmann, D. y L.F. de Oliveira Almeida

1987 Low holocene level (7700 to 3650 years ago) of Lake Titicaca (Bolivia). Palaeogeography, Palaeoclimatology, Palaeoecology 59, 315-323. 


\section{Notes}

Fuchs et al., 2006.

2 Shady Solís, 1999, 2000; Shady Solís and Leyva, 2003; Shady Solís et al., 2001; Shady Solís et al., 2009.

Moseley, 1973.

Aldenderfer, 1998.

Rick and Moore, 1999.

Rick, 1980.

Lynch, 1980a.

Lavallée et al., 1985.

Wheeler Pires-Ferreira et al., 1976; Kaulicke, 1980.

Benfer, 1990; Engel, 1980.

Stothert, 1985.

12 Kaplan and Lynch, 1999, Table 1, p. 266; the date reads 4490-4360 cal B.C., which is $6440-6310$ calBP.

13 Engel, 1988.

14 Lynch, 1980b.

15 Kaplan and Lynch, 1999, p. 269.

16 Bird and Hyslop, 1985.

17 Dillehay et al., 2012.

18 F. Engel mentions domesticated plants found in Chilca 1 and names the economy "agricultores incipientes" but sees the alimentation still based on the marine resources: "Además, el mar no estaba muy lejos, con la playa a cinco km. Me parece que si no hubiese sido necesario tomar agua durante los meses de sequía, de mayo a noviembre, los pobladores se habrían instalado más cerca a la playa, ya que los productos del mar constituían la base de su alimentación proteica". Engel, 1987, p. 54; T. Dillehay et al. mention regarding the economy of Huaca Prieta: "Although increases in plant species show a continuous greater reliance on cultigens, marine species dominated the diet throughout all phases." Dillehay et al., 2012, Suppl. p. 8.

19 Dillehay and Stackelbeck, 2011.

20 MacNeish et al., 1980; MacNeish et al., 1981; MacNeish et al., 1983.

21 Compare, for example, Flannery, 1973 and Pearsall, 1999, with further literature there.

22 Isla Cuadrado, 2008; Reindel, 2008; Reindel and Isla Cuadrado, 2006.

23 Strong, 1957.

24 Engel, 1981, p. 60; Engel, 1987.

25 Isla Cuadrado, 1990.

26 Vogt, 2011.

27 Vaughn and Linares Grados, 2006.

28 Donnan, 1964.

29 Burger and Glascock, 2000.

30 The radiocarbon measurements were conducted by the laboratories in Heidelberg, Germany (Hd) and Mannheim, Germany (MAMS) under the supervision of Bernd Krömer. All datings are AMS-datings. The modelling of the radiocarbon dates was conducted in co-operation with Ingmar Unkel, Institute for Ecosystem Research, CAU Kiel, Germany.

31 Bronk Ramsey, 1995; Bronk Ramsey, 2009.

32 Using the command, R-combine“.

33 Using the command „Sequence“.

34 Reimer et al., 2009.

35 Based on McCormac et al., 2002.

36 To pronounce its meaning as a non-settlement phase it was therefore numbered with 0 .
37 The determinations of the plant remains were accomplished by Gabriela Bertone of the Museo de Historia Natural de la Universidad San Marcos, Lima, Peru. Most sincerely thanks.

38 Prosopis trees are called ,algarrobo“ on the Central Peruvian coast, whereas the name ,huarango" or ,warango" is common on the South Peruvian coast Horkheimer, 1960, p. 77; there referenced to Prosopis juliflora.

39 The remains were weighted during their determination. The weights that were given as being less than $1 \mathrm{~g}$ incorporated into the calculation were considered as $0.5 \mathrm{~g}$.

40 Compare Aldenderfer, 1998.

41 Compare Wheeler Pires-Ferreira et al., 1976.

42 Compare Wing, 1980.

43 These analyses were conducted by the Bavarian State Collection of Palaeontology and Geology of the LMU in Munich by Stefan Hölzl, Christian Dekant and Susanne Hummel. The publication is in preparation.

44 Oficina nacional de evaluación de recursos naturales (ONERN), 1971, p. 42; based on the precipitation measured for the closest station in Palpa.

45 Eitel and Mächtle, 2008, p. 42.

46 Beresford-Jones, 2004, p. $21 \mathrm{f}$.

47 Mächtle, 2007, p. 136-143.

48 Oficina nacional de evaluación de recursos naturales (ONERN), 1971, p. 81 (text); Oficina nacional de evaluación de recursos naturales (ONERN), 1976 (map).

49 B. Mächtle, personal communication.

50 Eitel et al., 2005.

51 Mächtle, 2007.

52 Eitel et al., 2005.

53 Eitel et al., 2005, p. 149, Table 6.

54 Eitel et al., 2005, p. 149, Table 6.

55 Eitel and Mächtle, 2008.

56 Ibid.

57 Mächtle, 2007, p. 87.

58 B. Mächtle, personal communication.

59 Eitel et al., 2005: Eitel et al. reconstruct the ancient desert distribution as covering the zone of about $40 \mathrm{~km}$ inland from the coast. This reconstruction is used in the southern mapped area, where altitudes of above $450 \mathrm{~m}$ a.s.l. are found in the entire zone between the coast and the highlands.

60 Carré et al., 2005.

61 Oficina Nacional de Evaluación de Recursos Naturales (ONERN), 1976; mapped as "matorral desértico Montano cálido" (desertic warm mountainous shrubland).

62 Palomino, 2006, reported on recent observations of guanacos dismounting towards the flowering lomas in the area of San Fernando south of the Rio Grande estuary.

63 Based on the function "Path-Catchment" in the software ArcGIS 10; the factors for the surmounting of landscape gradients are based on Tobler 1961 but modified by Markus Steffen (in prep.) which he generously provided; rivers were weighted with a factor of $3 \mathrm{x}$.

64 Cross et al., 2000; Rowe et al., 2002; Wirrmann and de Oliveira Almeida, 1987, among others.

65 Schwalb et al., 1999.

66 Thompson et al., 1998.

67 Betancourt et al., 2000. 
68 Fontugne et al., 1999; Usselmann et al., 1999.

69 Holmgren et al., 2001.

70 Jenny et al., 2002.

71 Placzek et al., 2001.

72 Mächtle et al., 2010.
73 Sandweiss et al., 2007, even though the parallelism of the onset of early monumentality on the Central Peruvian coast with the onset of the ENSO has to be rejected, as the monumentality in Caral does not start before about 5000 BP.

74 Based on Everett, 1966.

75 Eitel, 2007. 